\title{
Simulation of water-limited growth of the forage shrub saltbush (Atriplex nummularia Lindl.) in a low-rainfall environment of southern Australia
}

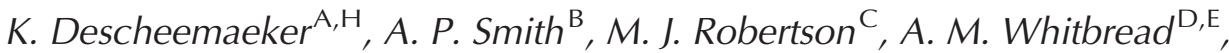 \\ N. I. Huth ${ }^{\mathrm{F}}$, W. Davoren ${ }^{\mathrm{B}}$, J. Emms ${ }^{\mathrm{G}}$, and R. Llewellyn ${ }^{\mathrm{B}}$ \\ APlant Production Systems, Wageningen University, PO Box 430, 6700 AK Wageningen, The Netherlands. \\ ${ }^{\mathrm{B}}$ CSIRO Agriculture Flagship, PMB 2, Glen Osmond, SA, 5064, Australia. \\ ${ }^{\mathrm{C}}$ CSIRO Agriculture Flagship, Private Bag 5, Wembley, WA 6913, Australia. \\ ${ }^{D}$ Crop Production Systems in the Tropics, Georg-August-Universität Göttingen, Grisebachstraße 6, 37077 \\ Göttingen, Germany. \\ EInternational Crops Research Institute for the Semi-arid Tropics (ICRISAT), Patancheru, Telengana, India. \\ ${ }^{F}$ CSIRO Agriculture Flagship, 203 Tor St, Toowoomba, Qld 4350, Australia. \\ GSouth Australian Research and Development Institute, Waite Campus, Hartley Grove, Urrbrae, SA 5064, Australia. \\ ${ }^{\mathrm{H}}$ Corresponding author. Email: katrien.descheemaeker@wur.nl
}

\begin{abstract}
Old man saltbush (Atriplex nummularia Lindl.) is a useful forage shrub for livestock in the low-rainfall areas of the world, and particularly in Australia. In these semi-arid and arid environments, saltbush is valuable for increasing the production from otherwise marginal areas of the farm and during drought periods when there are few feed alternatives. The ability to predict the growth and development of perennial forages such as old man saltbush in response to rainfall, soils and farm management is necessary for farming system planning and design purposes. A field experiment was conducted at Waikerie, South Australia, to inform the development of a new forage shrub model for use in the APSIM framework. The model takes into account the common setup of saltbush plantations in alley systems, by simulating light interception and water uptake for interacting shrub and inter-row zones separately. This is done by modelling the canopy and root system development. Field data across three soil types along a landscape catena showed that the model was able to satisfactorily predict daily biomass accumulation, partitioning into leaf and woody biomass, and regrowth after grazing. The model was sensitive to properties associated with the root system, and with limited parameterisation can be tailored to simulate different clonal cultivars. The model can now be used in the APSIM framework to assess temporal and spatial dynamics of forage systems combining shrubs with herbaceous pasture components.
\end{abstract}

Additional keywords: biomass partitioning, Eyres Green, farming systems model, radiation use efficiency, rooting depth.

Received 20 December 2013, accepted 7 May 2014, published online 7 October 2014

\section{Introduction}

Graziers in many arid regions of the world value saltbush (Atriplex spp.) as a browse forage for livestock (Wilson 1994; Le Houérou 2000; Ben Salem et al. 2010; Estell et al. 2012). In the low to medium rainfall areas of Australia (annual rainfall $<500 \mathrm{~mm}$ ), where mixed crop-livestock farming systems are widespread, the cost of supplementary feeding livestock through periods of feed scarcity is a major limitation (O'Connell et al. 2006; Ben Salem et al. 2010; Revell et al. 2013). Because of their ability to produce and maintain green, edible leaves during summer, saltbush and other forage shrubs complement annual plant systems in Mediterranean-type climates, where the majority of the spring- and winter-grown feed resources are dead and of poor nutritive value in summer (Papanastasis et al. 2008). Therefore, saltbush can be a key component of the farm feed-base during summer-autumn 'feed gaps' (Moore et al. 2009), as well as during drought periods (Norman et al. 2010).

Many saltbush species are native to Australia and occur in the rangelands, but some have also been extensively used in plantations, especially on land with marginal potential for cereal cropping (O'Connell et al. 2006; Monjardino et al. 2010). Saltbush has been planted on salt-affected as well as nonsaline land in southern Australia to provide feed, but also to combat salinity (Kok and George 1986; Barson et al. 1994), lower watertables (Barrett-Lennard and Malcolm 1999), provide vegetative cover to reduce soil erosion (Barrett-Lennard and Galloway 1996) or produce biomass for bioenergy production (George et al. 1999; Sochacki et al. 2012). Saltbush plantations on mixed farms may also foster biodiversity in the landscape 
(Seddon et al. 2009; Collard and Fisher 2010) via the provision of habitat for animals. Recent research (Norman et al. 2008, 2010; Thomas et al. 2009; Llewellyn et al. 2013), and the recognition of increased productivity of otherwise marginal land, has highlighted the important role of perennial shrubs in the low to medium rainfall zones of Australia (Revell et al.2013).

Old man saltbush (Atriplex nummularia Lindl.) is a perennial woody shrub that grows to about $2 \mathrm{~m}$ tall and $4 \mathrm{~m}$ in diameter in its natural environment (Jones 1970). It is extremely droughtand salt-tolerant and can be long-lived ( $>100$ years). Part of its drought tolerance is due to the plant's ability to accumulate salt in its leaves as it extracts water from the soil. Because of the high salt content of the leaves, animal intake is restricted and grazing livestock additionally need understory pasture, hay and/or grain, and access to drinking water (Warren et al. 1990; Barrett-Lennard et al. 2003; Norman et al. 2013). In the vast cropping areas of southern Australia, although the areas planted to saltbush are minor (Milthorpe et al. 2001; Llewellyn et al. 2010), economic analysis has shown that with only small plantings of saltbush, the productivity and profitability of mixed farms can be improved (Monjardino et al. 2010, 2014). Landscape variability is a common feature in the low-rainfall areas of southern Australia. Alternating dune-swale systems with deep sandy soils on the high dune positions and soils with subsoil constraints on the lower lying swale positions are not unusual. Farmers have long considered spatial variability in their decisions about farm design and management (Whitbread et al. 2008), with forage shrubs often planted on the marginal land types unsuitable for cropping, which results in more profitable enterprises (O'Connell et al. 2006; Monjardino et al. 2014).

The ability to predict the growth and development of a range of forage plants, including saltbush, is necessary to assess the effects of climate variability on farm feed supply, to evaluate different farming system configurations, and to estimate supplementary feeding requirements. Biophysical simulation models are useful to quantify components of the farm feed-base in response to seasonal variability, soil type and management (Bell et al. 2008). With the introduction of an increasingly diverse range of plant species to broaden the feed-base on rainfed, mixed farms in Australia (Nichols et al. 2007; Dear and Ewing 2008; Bell et al. 2012), there is a need to quantify the contribution of those components to overall farm production. Although well-validated simulation models exist in Australia for annual and perennial herbaceous species (Dolling et al. 2005), there is no model that can simulate leaf biomass production for saltbush, and the regrowth response following grazing. Saltbush is usually grown in alley systems with annual pasture growing between the lines of saltbush. This is similar to agro-forestry systems, and several agro-forestry models have been developed and discussed in the literature (for an overview, see Huth et al. 2002; Ellis et al. 2004). We chose to develop a saltbush module for application within the APSIM framework (Keating et al. 2003) because of its capability to simulate crop-tree interactions (Huth et al. 2002), its widespread use in Australia and internationally, and the wide array of validated crop and pasture modules with which the saltbush module can be linked (Holzworth et al. 2014). The component-based design of APSIM enables the individual models to interact via a common communications protocol (Holzworth et al. 2014), a characteristic that is common and recommended for agroforestry models (Muetzelfeldt 1995; Huth et al. 2002). For example, the plant modules interact with modules simulating processes such as carbon, nitrogen and phosphorus cycling, surface residue dynamics, water and solute fluxes, soil temperature and soil acidity.

This paper outlines the development of a saltbush model for the APSIM framework that can be applied to simulate biomass production and regrowth across seasons and soils. Model parameters are derived for two types of $A$. nummularia: $(i)$ a type originating from seed lines planted at the Waikerie nursery, called Waikerie saltbush; and (ii) the 'Eyres Green' clonal cultivar, called Eyres saltbush. The parameter values explaining physiological dynamics and saltbush growth and regrowth after grazing originate from a field experiment designed to assess the effect of soil variability on saltbush growth. Even though saltbush is often used for saltland rehabilitation, we chose to develop the model based on a dataset originating from a growing environment without salinity problems. This allows building of a potential growth model that can later be adjusted for a range of growth-limiting conditions.

\section{Methods}

Here we describe the saltbush model built for the APSIM framework and the collection of data from two field experiments, which were used to derive physiological and allometric parameters and to verify the model's performance.

\section{Model description}

The component-based design of the APSIM framework enables the individual models to interact via a common communications protocol. Here, the saltbush module communicates with existing soil and weather modules. As the basis of the saltbush module, we used the physiological framework described in detail by Huth et al. (2008). This framework has been successfully used in the development of models for other perennials such as Eucalyptus (Huth et al. 2002, 2010) and oil palm (Huth et al. 2014), and for the simulation of tree-crop interactions (Huth et al. 2002). Hence, the following description focuses only on the key components relevant for the saltbush system.

Leaf daily biomass growth is predicted from the total daily biomass growth and biomass partitioning mechanisms. Leaf area development is calculated based on the leaf biomass and the specific leaf area (SLA). Daily potential aboveground biomass production is simulated from the intercepted radiation and the radiation-use efficiency (RUE). Intercepted radiation is calculated from leaf area index (LAI), canopy area and shrub height, and the radiation extinction coefficient $(\mathrm{k})$. Actual daily biomass increase $(\Delta \mathrm{W})$ is derived from the potential growth, adjusted for temperature and water stresses.

The allometric relation between total plant mass (W) and leaf mass $\left(\mathrm{W}_{\mathrm{f}}\right)$ is described by a power function with two parameters c (leaf allometry constant) and $\mathrm{P}$ (leaf allometry power):

$$
\mathrm{W}_{\mathrm{f}}=\mathrm{cW}^{\mathrm{P}}
$$


From this, the amount of biomass partitioned to foliage each day $\left(\Delta \mathrm{W}_{\mathrm{f}}\right)$ is calculated as:

$$
\Delta \mathrm{W}_{\mathrm{f}}=\mathrm{c}(\mathrm{W}+\Delta \mathrm{W})^{\mathrm{P}}-\mathrm{W}_{\mathrm{f}}
$$

where $\Delta \mathrm{W}_{\mathrm{f}}$ is constrained to values between 0 and $\Delta \mathrm{W}$.

Any daily biomass increase that is not allocated to foliage is allocated to the woody biomass pool, $\mathrm{W}_{\mathrm{s}}$ :

$$
\Delta \mathrm{W}_{\mathrm{s}}=\Delta \mathrm{W}-\Delta \mathrm{W}_{\mathrm{f}}
$$

This approach results in all growth going into foliage until allometry is restored. It allows mimicking of the phenomenon that follows grazing of a greater proportion of growth being partitioned towards leaves than woody biomass.

Saltbush plantations are usually planted in alley arrangements and therefore have discontinuous groundcover, especially between rows. Light interception, water demand and water uptake are determined by the geometry of the alley system. In order to model this, we define two distinct zones: a shrub zone, coinciding with the row where shrubs are planted, and an interrow zone, coinciding with the rows between the shrub rows (Fig. 1). As the shrubs grow over time, the cover and density of photosynthesising biomass within the shrub zone vary, with consequences for light interception and water demand and uptake. The canopy leaf area $\left(\mathrm{LA}, \mathrm{m}^{2}\right)$ is calculated directly from foliage mass and a constant SLA $\left(\mathrm{m}^{2} \mathrm{~kg}^{-1}\right)$ :

$$
\mathrm{LA}=\mathrm{W}_{\mathrm{f}} \cdot \mathrm{SLA}
$$

and the LAI of the shrub zone is calculated by:

$$
\mathrm{LAI}=\frac{\mathrm{LA}}{\mathrm{d}_{\text {shrub }} \cdot \mathrm{d}_{\text {spacing }}}
$$

where $d_{\text {shrub }}$ is shrub zone width ( $m$ ), and $d_{\text {spacing }}$ is within-row shrub spacing (m) (see Fig. 1).

Shrub dimensions, including the projected canopy area and the shrub height, are used to adjust the Lambert-Beer law for the attenuation of light in canopies (see e.g. Duursma and Makela 2007) and determine the fraction of radiation intercepted by the shrub zone vegetation ( $F_{\text {int }}$, see Eqn 8 below and Fig. 1). Both projected canopy area and shrub height are predicted as a function of biomass. The relation between the projected canopy area (A) and the aboveground shoot biomass $\left(\mathrm{W}_{\mathrm{a}}, \mathrm{kg}\right)$ is described according to:

$$
\mathrm{A}=\mathrm{A}_{\mathrm{m}} \cdot\left(1-\mathrm{e}^{-\mathrm{a} \cdot \mathrm{W}_{\mathrm{a}}}\right)
$$

where $A_{m}$ is the maximum canopy area and $\mathrm{a}$ is the canopy area coefficient.

The shrub height $(\mathrm{h}, \mathrm{m})$ is predicted based on a relationship with woody biomass $\left(\mathrm{W}_{\mathrm{s}}, \mathrm{kg}\right)$ :

$$
\mathrm{h}=\mathrm{h}_{\max }-\left(\mathrm{h}_{\max }-\mathrm{h}_{0}\right) \cdot \mathrm{e}^{-\mathrm{b} \cdot \mathrm{W}_{\mathrm{s}}}
$$

(d)

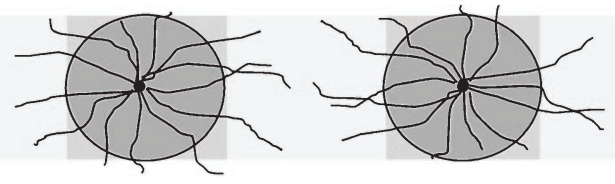

$(c)$
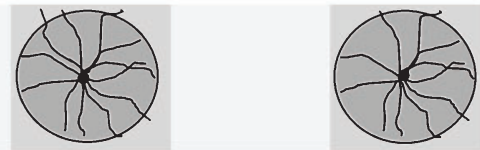

(b)
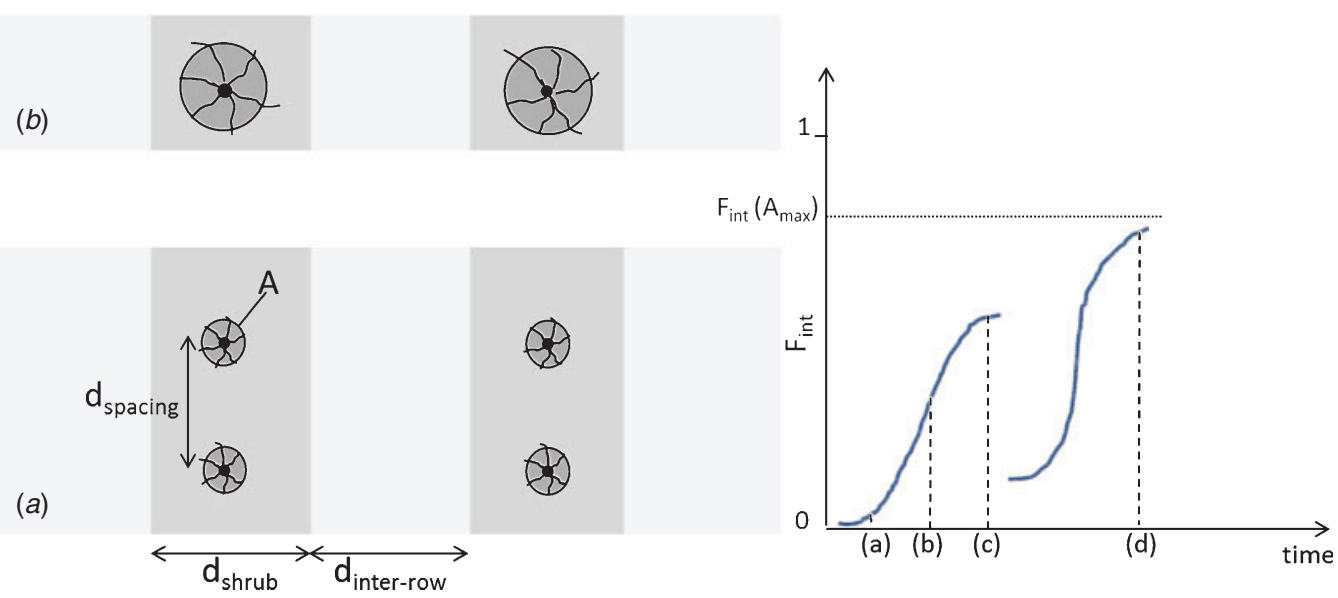

Fig. 1. Diagram of shrub and inter-row zones, with schematic drawings of stems, shrub canopies, and root systems as they develop over time (from $a$ to $d$ when maximum canopy cover $\mathrm{A}_{\max }$ is reached), with the stylised corresponding trend in the fraction of intercepted radiation in the shrub zone ( $\left.\mathrm{F}_{\text {int }}\right)$. 
where $\mathrm{h}_{0}$ and $\mathrm{h}_{\max }$ are the minimum and maximum shrub height and $\mathrm{b}$ is the height coefficient.

Using canopy area and height, the dimensionless variable $F_{\text {int }}$ provides an estimate of the fraction of the intercepted radiation in the shrub zone:

$$
F_{\text {int }}=\left(\frac{\mathrm{A}}{\mathrm{d}_{\text {shrub }} \cdot \mathrm{d}_{\text {spacing }}}+0.05 \frac{\mathrm{h}}{\mathrm{h}_{\max }}\right)\left(1-\mathrm{e}^{-\mathrm{k} \cdot \mathrm{LAI} \cdot \mathrm{d}_{\text {shrub }} \cdot \mathrm{d}_{\text {spacing }} / \mathrm{A}}\right)
$$

where $\mathrm{k}$ is the extinction coefficient, which is assumed to remain constant over the lifetime of the shrubs. As the shrub canopies expand laterally and in height, $F_{\text {int }}$ increases logistically to a maximum that is determined by the maximum canopy area (Fig. 1).

Finally, the daily aboveground shoot biomass growth at the individual shrub level is calculated by dividing the zone-level biomass growth by the shrub density $\left(\frac{1}{d_{\text {shrub }} \cdot d_{\text {spacing }}}\right)$, resulting in:

$$
\Delta \mathrm{W}=\mathrm{Rad} \cdot \mathrm{F}_{\text {int }} \cdot \mathrm{RUE} \cdot \mathrm{F}_{\mathrm{w}} \cdot \mathrm{F}_{\mathrm{t}} \cdot\left(\mathrm{d}_{\text {shrub }} \cdot \mathrm{d}_{\text {spacing }}\right)
$$

where $F_{w}$ and $F_{t}$ are the dimensionless coefficients for water and temperature limitations on growth, varying between 0 and 1; Rad is incident radiation $\left(\mathrm{MJ} \mathrm{m}^{-2} \mathrm{day}^{-1}\right)$; and RUE is the radiation use efficiency $\left(\mathrm{g} \mathrm{MJ}^{-1}\right)$.

Roots provide the interface between the crop and the soil module, with the root depth determining how much of the soil is accessible to the crop at any time. The root extraction front velocity (RFV) defines the rate of downward root growth. Root biomass is not directly modelled, so root: shoot biomass partitioning and the effect of local soil conditions on root growth are not taken into account. Soil water supply is determined by the soil water content above the crop lower limit in each layer occupied by roots, multiplied by the soil- and crop-specific extraction coefficient KL, which represents the fraction of plant-available soil water that can be extracted per day (Meinke et al. 1993). KL combines the effect of root length density and soil hydraulic properties. Crop water demand is calculated from potential evaporation by the Priestly-Taylor method (supplied by the soil water module in APSIM), corrected for vegetation cover by multiplying with $F_{\text {int }}$. This means that when shrub canopies (and root systems) cover only a small part of the shrub zone, water demand will be also be low. As the shrubs grow, $F_{\text {int }}$ increases (Fig. 1) and so does the water demand. If crop water demand is greater than the extractable soil water, the ratio of extractable water to water demand $\left(\mathrm{F}_{\mathrm{w}}\right)$ drops below one, thus lowering actual transpiration and $\Delta \mathrm{W}$. Soil nutrient uptake and nutrient effects on plant growth were not included in the model.

Because saltbush is commonly grown in widely spaced rows, often with companion herbaceous species between rows, it was necessary to allow for competition for soil water between saltbush and these species. To do this, the multi-point capability in APSIM was used (Huth et al. 2002; Keating et al. 2003) and two soil zones were used in this study (Fig. 1). In the shrub zone, saltbush extracts soil water, whereas in the inter-row zone, both a competing species and saltbush can access soil water. The model allows for different soil water extraction coefficients in the zones to account for a different density of saltbush roots and hence potential soil water extraction. The model has been designed to allow for simulation of an unlimited number of zones, and also 'blocks' of saltbush (as opposed to rows), in which case, saltbush roots have restricted access to the neighbouring inter-row zone only on one side of the saltbush. It is equally possible to simulate wider row plantings, for which three zones can be conceived, where zone 1 is restricted to saltbush, zone 2 is where saltbush and herbaceous pasture species compete, and zone 3 is where the herbaceous species grow without competition. In this paper, however, saltbush was considered to be planted in an alley system with two zones, and the effect of inter-row vegetation on the water balance was ignored.

The removal of biomass due to grazing is simulated in the model by removing $10 \%$ of leaf biomass and $1 \%$ of woody biomass every day during the grazing period. Those fractions can be modified by the user to represent different grazing intensities. Through Eqn 7, the biomass removal has an effect on shrub height.

\section{Parameter derivation}

Table 1 lists parameters values and their sources. Several parameters were derived from the field experiments described below; the remainder were sourced from the literature (as noted in Table 1) or derived from model calibration. Measurements of leaf and woody biomass, plant height and projected canopy area were used to derive model parameters. Minimum and maximum plant height $\left(\mathrm{h}_{0}\right.$ and $\left.\mathrm{h}_{\max }\right)$ as well as maximum canopy area $\left(\mathrm{A}_{\mathrm{m}}\right)$ were derived directly from the measured data. The parameters $\mathrm{c}$ and $\mathrm{P}$ regulating biomass partitioning (Eqn 1), and the canopy and height coefficients ( $a$ and b, Eqns 6 and 7, respectively), were derived from fitting the functions of the equations to the data for Waikerie saltbush and Eyres saltbush. Minimum, optimum and maximum temperatures for shrub growth were derived from Gates and Muirhead (1967) and Le Houérou (1992) and cross-checked by comparing measured biomass growth rates against daily temperature. The SLA $\left(\mathrm{m}^{2} \mathrm{~kg}^{-1}\right)$ was determined at each sampling time for a leaf sample that was processed through a leaf area meter for area determination and weighed after drying. For both saltbush types, SLA deviated only slightly from $7.7 \mathrm{~m}^{2} \mathrm{~kg}^{-1}$ over time, and it was decided to keep the parameter at that value. The canopy light extinction coefficient was set at 0.5 , which is a common value for canopies with randomly distributed leaves (Monteith and Unsworth 1990; Huth et al. 2008). A model sensitivity analysis was conducted to explore changes in simulated leaf biomass resulting from changes in model input parameters. With limited direct measurements of root characteristics, this shed light on plausible values for the root parameters and highlighted where accurate measurements are most needed. As such, the sensitivity of simulated leaf biomass of Waikerie saltbush was analysed for varying values of maximum rooting depth $\left(D_{\max }\right), R F V$, and $\mathrm{KL}$ for the shrub and inter-row zones.

\section{Field experiment}

A field experiment at Waikerie, South Australia $\left(34^{\circ} 17^{\prime} \mathrm{S}\right.$, $140^{\circ} 01^{\prime} \mathrm{E}$ ), was monitored from 2009 to 2013 to derive model parameters. The field experiment was designed to enable the collection of a time-series of aboveground biomass (leaf and woody biomass components) and shrub dimensions before and 
after grazing for parameter derivation and model verification. Daily weather data for Waikerie were sourced from the SILO database (www.longpaddock.qld.gov.au/silo). During the experiment, the summer of 2010-11 was the wettest on record, and the following summer was wetter than normal (Table 2). By contrast, the summer of 2012-13 was extremely dry.

The main 'landscape' experiment was established along a dune-swale transect and measured 150 by $80 \mathrm{~m}$. The aim of this experiment was to monitor shrub development, leaf biomass production and regrowth after grazing, and to capture the effects of soil variability. Shrubs were planted at $3.5-\mathrm{m}$ intervals in rows spaced $4.5 \mathrm{~m}$ apart, along a catena. Ten rows of Waikerie saltbush were alternated with rows planted with Rhagodia preissii Moq., another forage shrub. Eyres saltbush was planted in two rows. The soils along the catena were representative of the dune-swale system, which is a typical landscape feature of the study region (Whitbread et al. 2008). The soils were classified as Hypocalcic Calcarosols (Isbell 2002), underlain by a massive, calcrete layer varying from free concentrations to a strongly cemented pan. The dune soil at the highest elevation was a deep $(>1.5 \mathrm{~m})$, light loamy sand, whereas the soils on the mid and swale positions were characterised by a sandy topsoil and a marked shift to heavier clay texture at $\sim 20-30 \mathrm{~cm}$. The swale soil, with a $\mathrm{pH}$ of 8.5 below $10 \mathrm{~cm}$, showed subsoil constraints with boron (up to $17 \mathrm{mg} / \mathrm{kg}$ ) and accumulated salts (electrical conductivity up to $1.1 \mathrm{dS} \mathrm{m}^{-1}$ ) starting at $\sim 50 \mathrm{~cm}$. Extractable soil water and other soil properties for use in APSIM were based on those

Table 1. List of parameters for the saltbush model

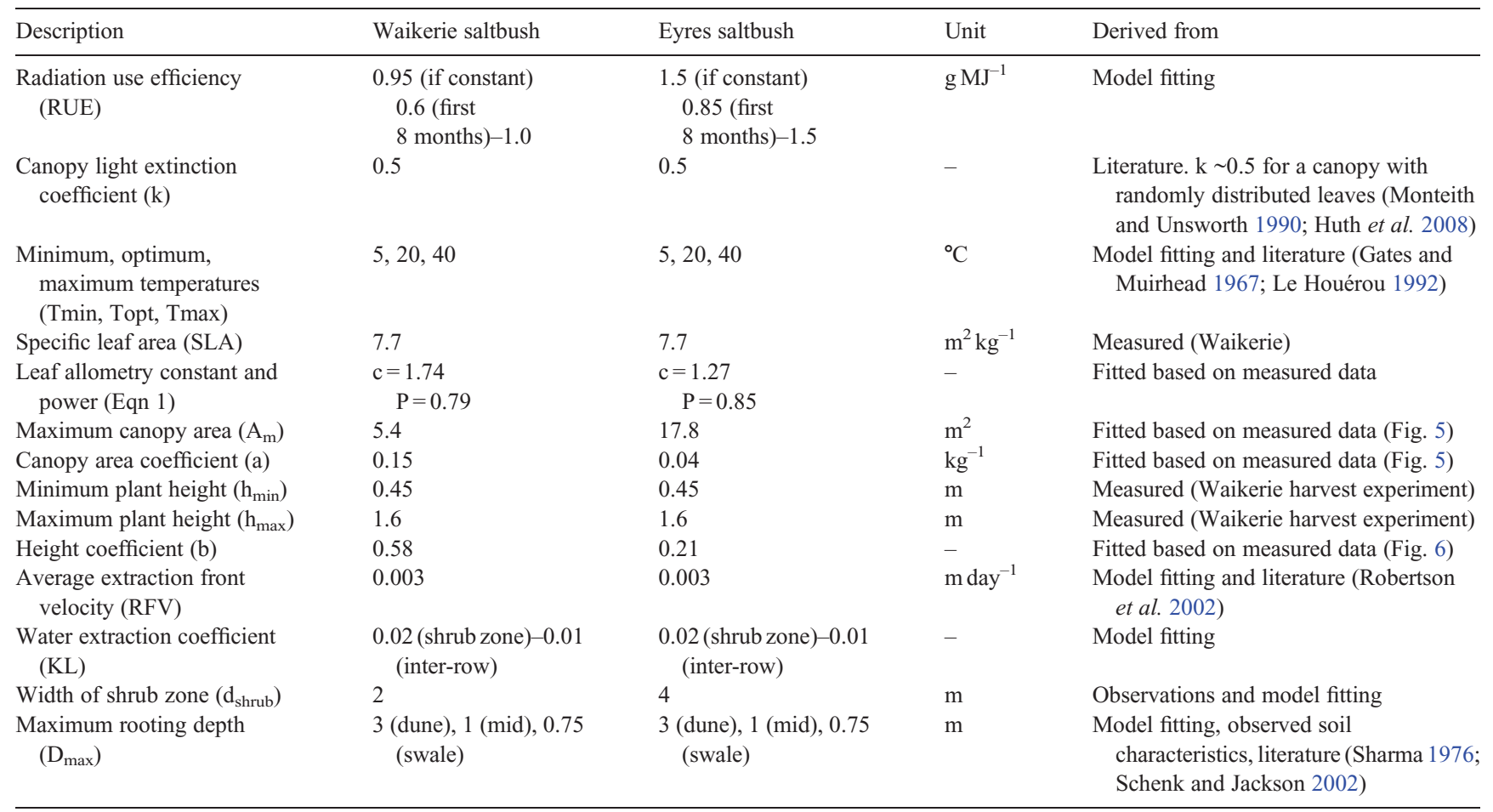

Table 2. Monthly rainfall and average minimum and maximum temperature during the trial at Waikerie and the longterm average (LTA)

\begin{tabular}{lrrrrrrrrrrrrr}
\hline & \multicolumn{1}{c}{ Monthly rainfall $(\mathrm{mm})$} & \multicolumn{4}{c}{ Monthly average minimum-maximum temperature $\left({ }^{\circ} \mathrm{C}\right)$} \\
& 2009 & 2010 & 2011 & 2012 & 2013 & LTA & 2009 & 2010 & 2011 & 2012 & 2013 & LTA \\
\hline Jan. & 0 & 16 & 32 & 14 & 0 & 16 & $15-35$ & $15-34$ & $16-33$ & $16-32$ & $14-33$ & $15-32$ \\
Feb. & 0 & 15 & 71 & 7 & 11 & 21 & $15-33$ & $17-33$ & $17-30$ & $15-31$ & $16-33$ & $15-32$ \\
Mar. & 1 & 30 & 71 & 47 & 2 & 14 & $12-29$ & $13-29$ & $13-26$ & $12-28$ & $14-30$ & $13-29$ \\
Apr. & 26 & 28 & 2 & 4 & 25 & 17 & $9-24$ & $11-25$ & $9-24$ & $9-26$ & $10-25$ & $10-24$ \\
May & 5 & 56 & 21 & 34 & 37 & 26 & $8-19$ & $6-21$ & $7-19$ & $5-20$ & $8-21$ & $8-20$ \\
June & 39 & 9 & 9 & 16 & 37 & 24 & $5-17$ & $5-16$ & $4-18$ & $4-16$ & $5-16$ & $5-17$ \\
July & 27 & 26 & 20 & 29 & 15 & 23 & $5-17$ & $3-16$ & $4-17$ & $4-16$ & $5-17$ & $5-16$ \\
Aug. & 22 & 22 & 27 & 16 & 13 & 24 & $6-20$ & $5-16$ & $6-19$ & $5-18$ & $6-19$ & $6-18$ \\
Sept. & 45 & 64 & 8 & 8 & 23 & 25 & $8-22$ & $7-18$ & $6-23$ & $6-23$ & $9-24$ & $7-21$ \\
Oct. & 17 & 42 & 28 & 6 & & 27 & $9-24$ & $9-24$ & $10-24$ & $8-26$ & $9-24$ \\
Nov. & 103 & 16 & 84 & 0 & & 22 & $15-33$ & $12-27$ & $13-29$ & $12-30$ & \\
Dec. & 19 & 192 & 62 & 22 & & 21 & & $14-31$ & $14-29$ & $13-30$ & $14-31$ & \\
\hline
\end{tabular}


reported by Whitbread et al. (2008) and Monjardino et al. (2013) (Table 3).

A second experiment (named the 'harvest' experiment) was established on the dune soil, where six alternating blocks of 20 Waikerie saltbush and Eyres saltbush shrubs were planted for destructive measurements of aboveground woody and leaf biomass over time. This experiment complemented the leaf biomass assessment in the landscape experiment with more detailed information on allometry and biomass partitioning that was needed for model parameterisation.

Waikerie saltbush seedlings were planted on 21 May 2009 in the landscape experiment. On 1 July, the harvest experiment was established, together with the Eyres saltbush rows in the landscape experiment. Prior to planting, weeds were killed with glyphosate. Inter-rows and shrub surroundings were kept free of other vegetation or crops during the first year of establishment. During the winter of 2010, low-density wheat was grown in the inter-rows and the stubble left standing as a protection against wind erosion. In 2011, a self-regenerating medic-based pasture (Medicago littoralis cv. Angel and M. truncatula cv. Caliph) was established in the inter-rows and lasted until the end of the data collection period. Pasture production in the inter-row was observed to be very low. From 1 April until 11 May 2011, all shrubs in both trials were grazed for a first time by dry ewes. Remaining leaf biomass was visually assessed through scoring. The scores ranged from 1 to 5 , corresponding to $0-20 \%$ and $80-100 \%$ of foliage removal. At the end of the first grazing period, there was virtually no residual leaf biomass on the shrubs. In 2012, shrub grazing was more intermittent, taking place from 24 to 30 April, then again from 1 to 14 June. By the end of this period, the scoring revealed that $30 \%$ of the leaf biomass remained for Waikerie saltbush. Eyres saltbush was grazed to a lesser extent and postgrazing measurements were stopped for Eyres saltbush in 2012. Waikerie saltbush was grazed a third time in 2013 between 25 April and 20 May, with a similar amount of leaf biomass removed as during the second grazing. The grazing experiment was approved through the Primary Industries and Resources South Australia Animal Ethics Committee (application \#24/08).

Measurements of leaf biomass and shrub dimensions (height, canopy width along and across the shrub-row line) were taken every 3 months from November 2009 to September 2013 for each shrub along the catena in the landscape trial. Leaf biomass was assessed with the Adelaide technique (Andrew et al. 1976), which involves the visual assessment of the number of 'units' in a shrub. An 'Adelaide unit' consists of several branches with leaves, of which the smallest shrubs generally have one or two, whereas the biggest shrubs in a sample can consist of up to 100 units. At each sampling time, the Adelaide technique was calibrated through regression of the Adelaide numbers of 8-10 shrubs against their actual leaf biomass, which was obtained by manually stripping the branches and weighing the leaf biomass after drying. Adelaide numbers were determined for all shrubs in the saltbush alleys of the landscape trial and then converted into leaf biomass using the regression function. Based on the shrub position along the catena, average leaf biomass production and shrub dimensions were determined for the three distinct soil types: dune (deep sandy soil), mid (sand-clay), and swale (sand-clay, subsoil constraints). From October 2010, the measurement frequency was reduced to every fourth shrub, and these shrubs were also scored after grazing. In the harvest experiment, measurements were conducted every 3 months to March 2012. At each sampling time, three Waikerie saltbush and three Eyres saltbush shrubs were randomly chosen and destructively harvested for total woody and leaf biomass assessments. In addition, canopy dimensions, shrub height and Adelaide number were determined for every harvested shrub. As shrub height was not sufficiently reduced during the second grazing, shrubs were mechanically cut on 18 September 2012 to reduce the height to a uniform level across the experiment, and height is not reported thereafter. Trimming shrub height can be an important management practice to prevent the shrubs

Table 3. Soil physical parameters for the dune, mid and swale positions in the landscape trial at Waikerie as used in APSIM

\begin{tabular}{lcccccc}
\hline $\begin{array}{l}\text { Landscape } \\
\text { position }\end{array}$ & $\begin{array}{c}\text { Depth } \\
(\mathrm{cm})\end{array}$ & $\begin{array}{c}\text { Bulk density } \\
\left(10^{3} \mathrm{~kg} \mathrm{~m}^{-3}\right)\end{array}$ & Air dry & $\begin{array}{c}\text { Water content }\left(\mathrm{mm} \mathrm{mm}^{-1}\right) \text { at: } \\
\text { Lower } \\
\text { limit }\end{array}$ & $\begin{array}{c}\text { Drained } \\
\text { upper limit }\end{array}$ & Saturation \\
\hline Dune & $0-10$ & 1.5 & 0.02 & 0.04 & 0.08 & 0.37 \\
& $10-20$ & 1.7 & 0.03 & 0.04 & 0.07 & 0.32 \\
& $20-40$ & 1.6 & 0.05 & 0.05 & 0.09 & 0.33 \\
& $40-60$ & 1.6 & 0.05 & 0.05 & 0.11 & 0.35 \\
& $60-80$ & 1.6 & 0.05 & 0.05 & 0.17 & 0.35 \\
& $80-100$ & 1.7 & 0.14 & 0.14 & 0.19 & 0.30 \\
& $100-120$ & 1.6 & 0.14 & 0.14 & 0.21 & 0.31 \\
& $120-150$ & 1.6 & 0.14 & 0.14 & 0.19 & 0.32 \\
& $150-200$ & 1.6 & 0.14 & 0.14 & 0.19 & 0.32 \\
& $200-300$ & 1.6 & 0.14 & 0.14 & 0.19 & 0.32 \\
Mid and swale & $0-10$ & 1.5 & 0.02 & 0.02 & 0.08 & 0.37 \\
& $10-20$ & 1.7 & 0.02 & 0.03 & 0.07 & 0.32 \\
& $20-40$ & 1.5 & 0.10 & 0.13 & 0.28 & 0.38 \\
& $40-60$ & 1.6 & 0.19 & 0.19 & 0.30 & 0.35 \\
& $60-80$ & 1.5 & 0.19 & 0.19 & 0.28 & 0.38 \\
& $80-100$ & 1.5 & 0.19 & 0.19 & 0.28 & 0.38 \\
\hline
\end{tabular}


from growing out of reach of the sheep. The new shrub height after trimming was similar to the predicted shrub height based on Eqn 7.

\section{Results}

\section{Biomass production in the landscape trial}

Leaf biomass production in the first 18 months before grazing amounted to 2.4 and $8.6 \mathrm{~kg} \mathrm{shrub}^{-1}$ for Waikerie and Eyres saltbush, respectively (Fig. 2). In the year after the first grazing, leaf biomass recovered quickly to exceed values before grazing. After the second grazing, regrowth for Waikerie saltbush was not compromised, and the first measurement after the third grazing in 2013 again indicated good recovery from defoliation. Soil variation along the catena strongly influenced shrub growth even though differences in absolute terms were not large in the first months. However, from the onset, leaf biomass production on the swale soils ranged between $40 \%$ and $60 \%$ of the leaf biomass on the dune soils for both Waikerie and Eyres saltbush, with the mid-slope position in-between (Fig. 2). Leaf biomass production of Waikerie saltbush amounted to $\sim 1.4 \mathrm{tha}^{-1}$ on the swale and $2.7 \mathrm{tha}^{-1}$ on the dune position in the year after the first grazing. In that same year, the more productive Eyres saltbush achieved leaf biomass of 4.3 and $6.1 \mathrm{tha}^{-1}$ on the swale and dune position, respectively. After the second grazing, leaf biomass production of Waikerie saltbush peaked at similar levels of $1.5-2.3 \mathrm{tha}^{-1}$. However, in the very dry summer of 2013, the leaf biomass declined after reaching a peak and the differences between the landscape positions dissipated.

\section{Biomass partitioning, shrub dimensions and leaf area index}

The leaf:shoot ratio derived from the harvest experiment was slightly different for the two saltbush types and evolved over time (Fig. 3). In the first year after planting, the ratio declined from 0.7 to 0.5 for Waikerie saltbush and from 0.6 to 0.4 for Eyres saltbush. After grazing, the ratio increased from $<0.1$ to 0.3 for Waikerie saltbush and to 0.2 for Eyres saltbush. The recovery of the leaf: shoot ratio after grazing is achieved by using assimilates primarily for foliage production. The ability of the shrubs to adjust biomass partitioning over time and in response to grazing is simulated in the model by Eqn 1. Fitting this function to the data from the harvest experiment resulted in leaf allometry constant and power (c and P) values of 1.74 and 0.79 for Waikerie saltbush and 1.27 and 0.85 for Eyres saltbush (Table 1).

Shrub height in the landscape experiment evolved similarly for both saltbush types, with small differences between soil types (Fig. 4). During the first grazing, shrub height was reduced from $\sim 1.5$ to $1 \mathrm{~m}$. For Eyres saltbush on the dune and mid-slope positions, sheep reduced the height to only $1.2-1.4 \mathrm{~m}$. This difference is related to the fact that the Eyres saltbush canopies on those positions were already very large (diameters of up to $4 \mathrm{~m}$ ), causing difficulties for the sheep to access the centre of the canopy. The second grazing was less heavy and reduced height only slightly, by $<10 \mathrm{~cm}$. In line with leaf biomass production, projected canopy area and canopy volume (not shown) increased over time and along the catena from the swale to the dune position of the landscape experiment (Fig. 4). Eyres saltbush developed a much larger canopy, with a maximum diameter after grazing in the range $3.5-5 \mathrm{~m}$ along the catena, compared with 2-3 m for Waikerie saltbush.

The harvest experiment data on canopy area and total aboveground shoot biomass allowed fitting of Eqn 6 and estimating the parameters for maximum canopy $\left(A_{m}\right)$ and canopy area coefficient (a) (Fig. 5, Table 1). With Eyres saltbush developing much wider canopies than Waikerie saltbush, the shrub zones in the alley system of the landscape experiment were larger for Eyres saltbush than for Waikerie saltbush. This is represented in the model by $\mathrm{d}_{\text {shrub }}$ parameters of 4 and $2 \mathrm{~m}$, respectively (Table 1). Data on height and woody biomass from the same experiment allowed fitting of Eqn 7 and determination of the parameters $h_{0}$ and $h_{\max }$ (minimum and maximum height), as well as the height coefficient b (Fig. 6, Table 1).

The LAI, which was calculated at the shrub zone level, reached a peak of 2.8 for Waikerie saltbush and 4.7 for Eyres saltbush during the period before first grazing on the dune position. In line with leaf biomass regrowth, LAI recovered after the first grazing to 4.7 and 5.3 for Waikerie and Eyres saltbush on the dune position. At downslope positions of the catena, LAI was roughly $30-50 \%$ of the maximum at the dune position, in line with the trend in leaf biomass.
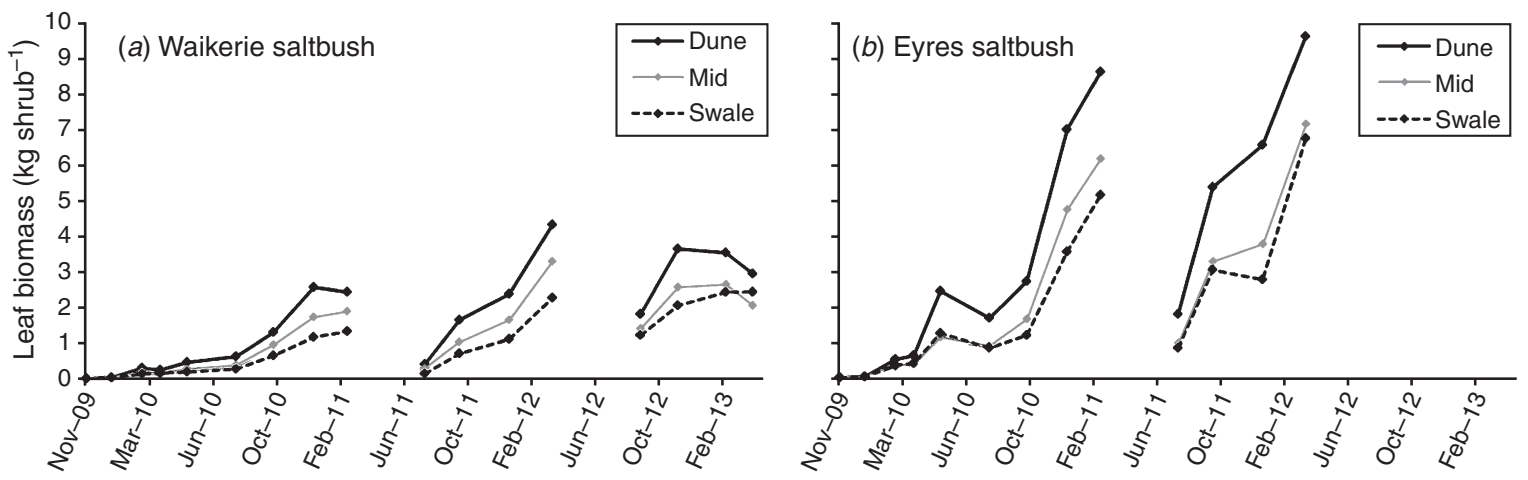

Fig. 2. Leaf biomass per shrub for $(a)$ Waikerie saltbush and $(b)$ Eyres saltbush on three landscape positions (dune, black line; mid, grey line; swale, dotted line) in the landscape experiment at Waikerie. Breaks in the lines represent the grazing periods. 


\section{The saltbush model}

Model parameters that were directly measured or derived from fitting equations have been described in the previous section. Here, we present the model predictions and compare them with observations from the landscape experiment. We also present model sensitivity analyses for varying values of three parameters describing belowground processes, namely RFV, KL and $\mathrm{D}_{\max }$.

With an RUE of $0.95 \mathrm{~g} \mathrm{MJ}^{-1}$ for Waikerie saltbush and $1.5 \mathrm{~g} \mathrm{MJ}^{-1}$ for Eyres saltbush, and using the parameter values in Table 1, the model reproduces the time-course of leaf biomass production reasonably well, but early growth on all landscape

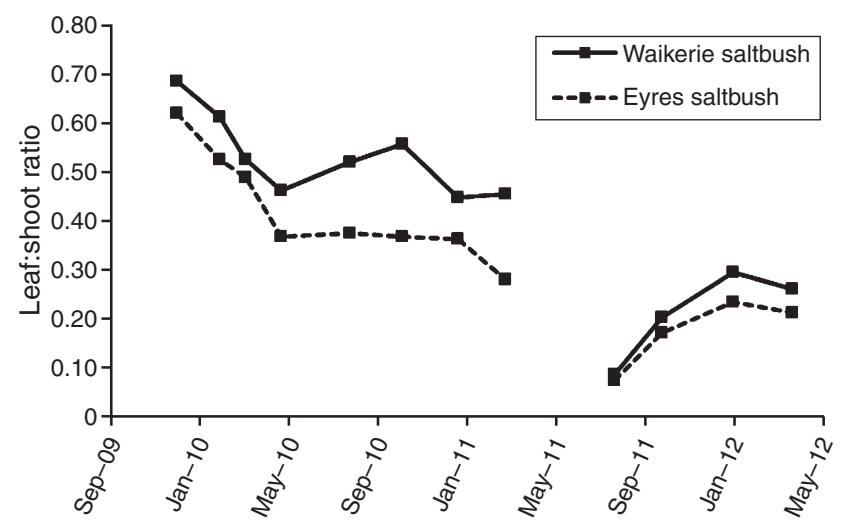

Fig. 3. Leaf: shoot ratio over time for Waikerie saltbush (-) and Eyres saltbush $(. .$.$) before and after grazing in the harvest experiment at Waikerie.$ positions is overestimated (Fig. 7). A closer fit with the early observations was obtained by incorporating a time-dependent RUE, characterised by a low value in the early stages and a high value later (Fig. 7). For Waikerie saltbush, a good fit for all landscape positions was obtained with a value of $0.6 \mathrm{~g} \mathrm{MJ}^{-1}$ in the first 8 months after planting and $1.0 \mathrm{~g} \mathrm{MJ}^{-1}$ afterwards (Fig. 8). Only in the summer of 2013, growth on the dune position was overestimated. For Eyres saltbush, the time-dependent RUE values of 0.85 and $1.50 \mathrm{~g} \mathrm{MJ}^{-1}$ resulted in acceptable model accuracy on all landscape positions (Fig. 9). Shrub growth and leaf biomass production was much larger for Eyres saltbush than Waikerie saltbush, resulting in different parameter values for biomass partitioning, allometry and RUE (Table 1). The model was less accurate for Eyres than for Waikerie saltbush. In addition, the measurement error was higher for Eyres saltbush, for which fewer shrubs were measured and the accuracy of the measurements was sometimes compromised by the large size of the shrubs.

Sensitivity analysis showed that the simulated leaf biomass production was most sensitive to the maximum rooting depth, with a best fit obtained for values of 3,1 and $0.75 \mathrm{~m}$ for the dune, mid and swale positions (Fig. 10). Simulated leaf biomass was also sensitive to the root extraction front velocity, with a good fit for the dune position with a minimum RFV of $3 \mathrm{~mm}^{-1}{ }^{-1}$. An RFV value of $0.75 \mathrm{~mm} \mathrm{day}^{-1}$ for the mid and swale positions resulted in a better fit for the early stages of shrub growth (Fig. 10). A lower value for the mid and swale positions is consistent with the subsoil constraints and the heavier texture found at these locations. The model output was not very sensitive to the KL

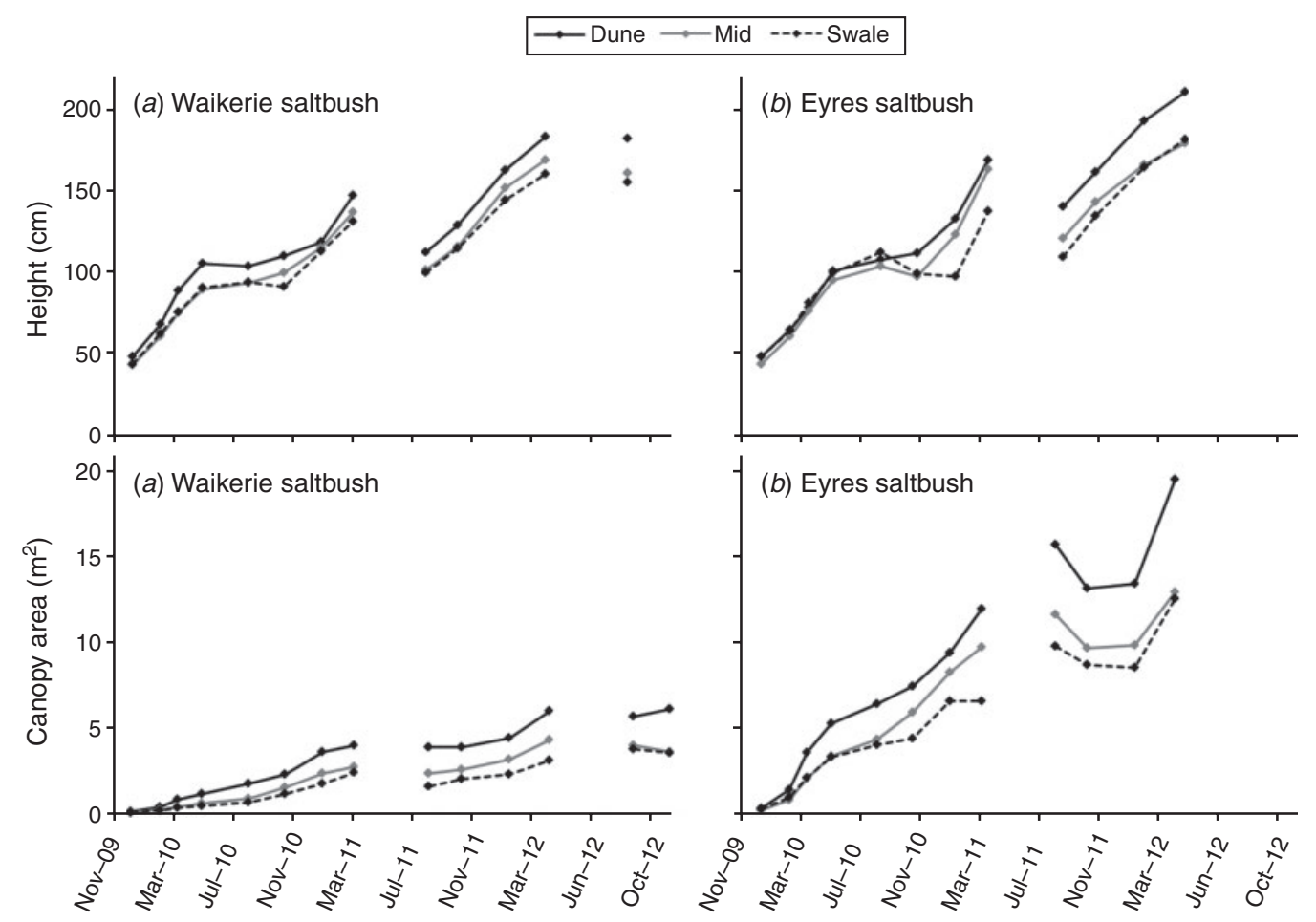

Fig. 4. Shrub dimensions over time for (a) Waikerie saltbush and (b) Eyres saltbush on three landscape positions (dune, black full line; mid, grey line; swale, black dotted line) in the landscape experiment at Waikerie. Shrub height, upper panes; shrub canopy area, lower panes. Breaks in the lines represent the grazing periods. 


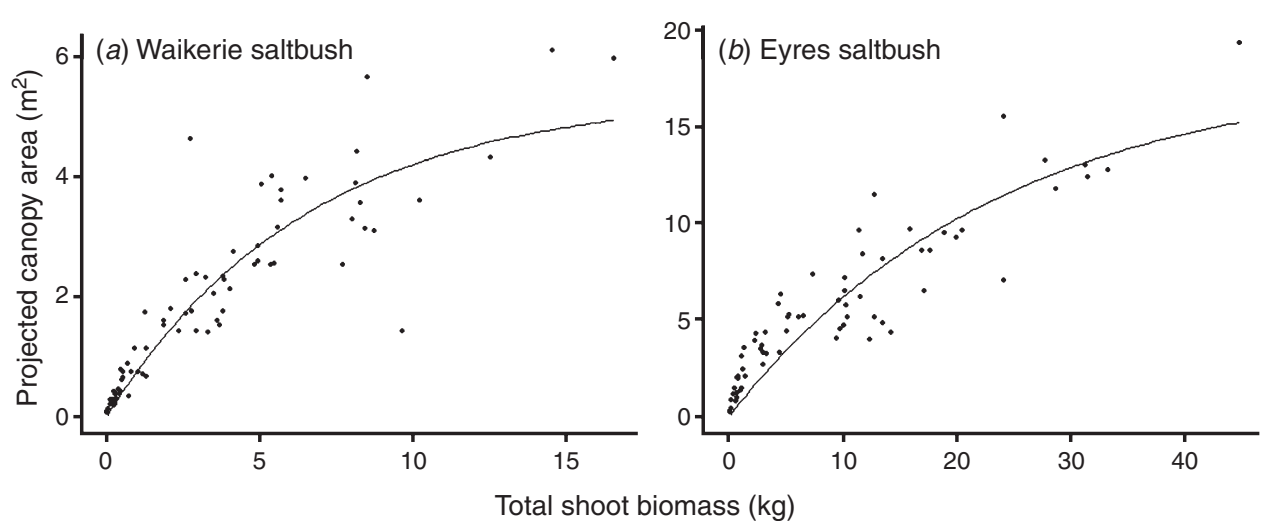

Fig. 5. Scatterplot and fitted function relating the projected canopy area and total shoot biomass for (a) Waikerie saltbush $\left(y=5.4\left(1-\mathrm{e}^{-0.15 x}\right), n=75\right.$, residual standard error $\left.=0.67 \mathrm{~m}^{2}\right)$; and $(b)$ Eyres saltbush $\left(y=17.8\left(1-\mathrm{e}^{-0.04 x}\right), n=69\right.$, residual standard error $\left.=1.82 \mathrm{~m}^{2}\right)$. Note the different scales of the $x$ - and $y$-axes in (a) and $(b)$.

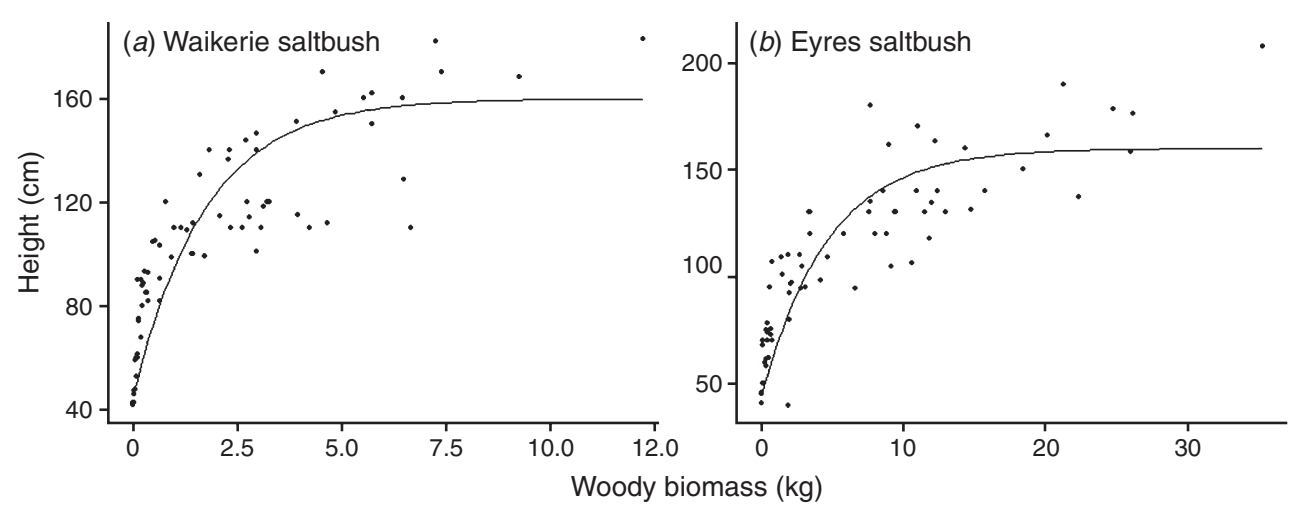

Fig. 6. Scatterplot and fitted function relating the shrub height and woody biomass for (a) Waikerie saltbush $\left(y=160-115 \mathrm{e}^{-0.58 x}, n=75\right.$, residual standard error $\left.=20 \mathrm{~cm}\right)$; and $(b)$ Eyres saltbush $\left(y=160-115 \mathrm{e}^{0.21 x}, n=69\right.$, residual standard error $=21 \mathrm{~cm})$. Note the different scales of the $x$ - and $y$-axes in $(a)$ and $(b)$.

parameters (results not shown), and a good fit was obtained with a value of 0.02 and 0.01 for the shrub zone and the interrow zone, respectively.

\section{Discussion}

Saltbush plantations are often established in alley systems. The model deals with this system both above- and belowground by distinguishing between the so-called shrub and inter-row zones, which is a common approach also in models of agroforestry systems (e.g. Van Noordwijk and Lusiana 1998; Lefroy et al. 2001). Whereas available water and nutrients are belowground factors determining plant growth, above the ground, plant growth is mostly influenced by light. In line with other models of woody perennials, light interception is influenced by canopy dimension and leaf area, which, in turn, are calculated based on the mass of woody and leafy structures (e.g. Friday and Fownes 2001). In addition, the structure and spacing of the vegetation alleys influence light interception, which is simulated with Eqn 8. Whereas aboveground shrub growth processes are restricted to the shrub zone, below the ground, the model allows roots to grow laterally into the inter-row zone, where they can extract water (Fig. 1) (Huth et al. 2002). We assumed the water extraction parameter KL of the inter-row to be half that of the shrub zone KL (Table 1). As a result, the model also simulates water extraction by the shrubs in the inter-row, albeit more slowly than in the shrub zone. This was confirmed by soil moisture sampling after a long dry period in June 2013, which showed that the soil profile in the inter-row zone was as dry as the shrub zone profile, and considerably drier than the soil profile at a similar position in a neighbouring crop field. The fact that the shrub roots are able to invade and dry out the inter-row zone is confirmed by evidence from an alley system experiment with woody perennials and annual crops in similar low-rainfall environments in South Australia, where crop grain yields decreased within $2-5 \mathrm{~m}$ of shrub belts because of the shrubs' water use (Unkovich et al. 2003). Knight et al. (2002) also found that shrub belts used water from within a few metres from the edge with adjacent cropland. This is in line with the vast body of literature on water use in agroforestry systems (e.g. Van Noordwijk et al. 1996; Lefroy et al. 2001).

The saltbush model uses a time-dependent RUE, with a lower value for the juvenile and a higher value for the mature shrub stages. With a constant value for RUE, the model tended to 


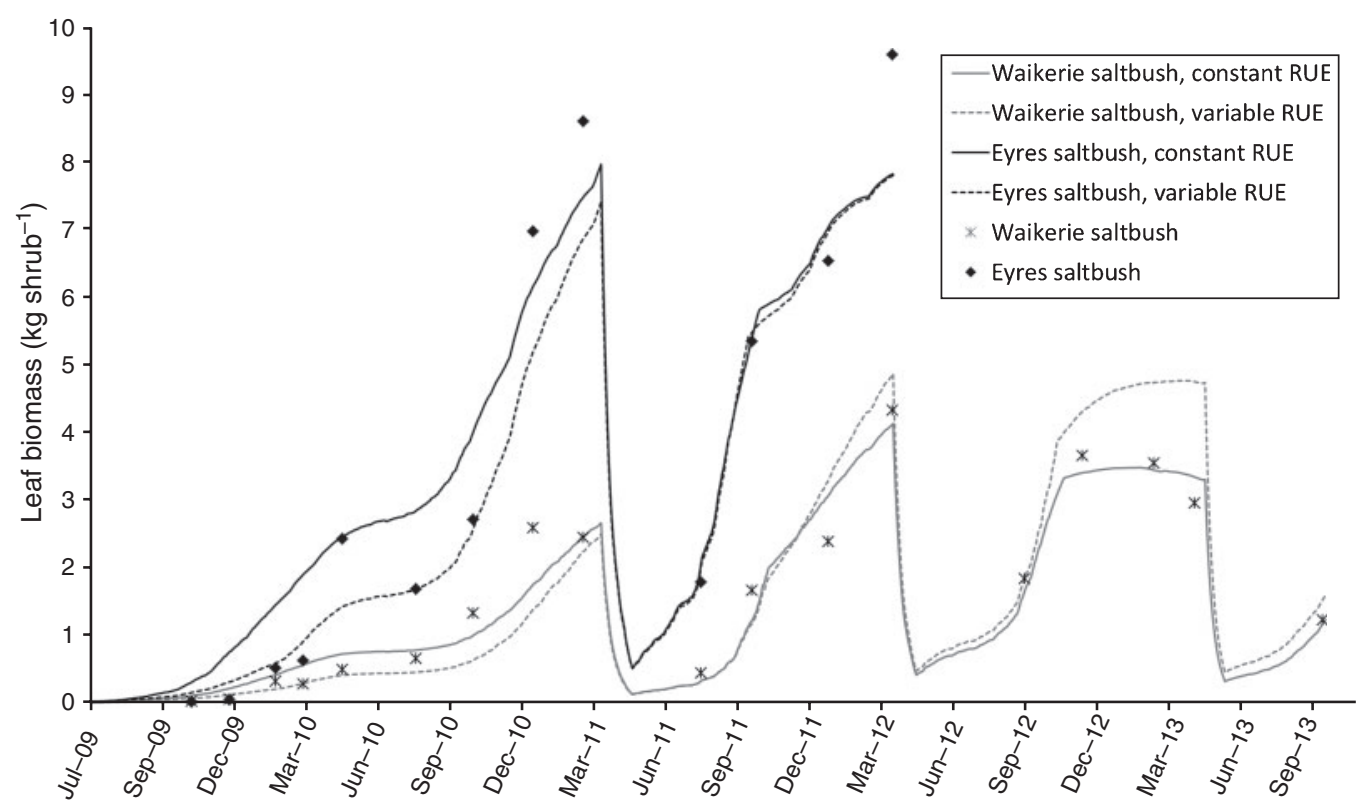

Fig. 7. Model predictions and observations of leaf biomass for Waikerie saltbush $(*)$ and Eyres saltbush $(\diamond)$ at the dune position with a constant radiation-use efficiency (RUE) of $0.95 \mathrm{~g} \mathrm{MJ}^{-1}$ (grey lines) and $1.50 \mathrm{~g} \mathrm{MJ}^{-1}$ (black lines) and a time-dependent RUE of 0.6 and $1.0 \mathrm{~g} \mathrm{MJ}^{-1}$ (dotted grey lines) and 0.85 and $1.50 \mathrm{~g} \mathrm{MJ}^{-1}$ (dotted black lines) and parameters of Table 1 .

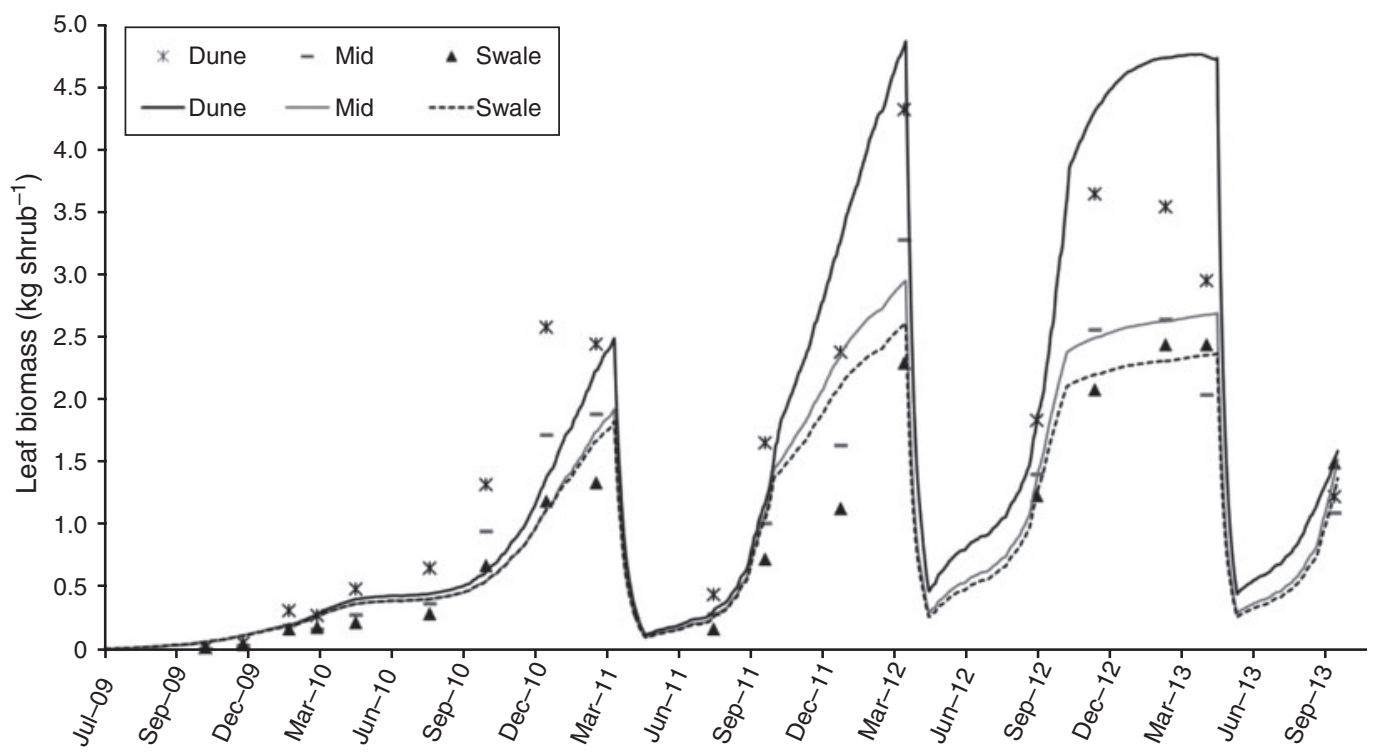

Fig. 8. Model predictions and observations of leaf biomass for Waikerie saltbush at three landscape positions (dune, black line and stars; mid, grey line and rods; swale, dotted line and triangles) with a time-dependent radiation-use efficiency of 0.6 and $1.0 \mathrm{~g} \mathrm{MJ}^{-1}$ and parameters of Table 1 .

over-predict leaf biomass production in the first year following planting for shrubs in all landscape positions (Fig. 7). This effect continued up until 18 months for the mid and swale positions. Our data thus show that saltbush plants in different growth stages behave differently, and this was captured in the model with time-dependent RUE parameterisation. Differences in biomass production between seedling and regrowth stages have been observed for other perennial plants. For lucerne (Medicago sativa L.), for example, different values for parameters governing physiological processes are required to represent the seedling and regrowth phases (Probert et al. 1998; Thiébeau et al. 2011). Experimental work showed that RUE, leaf area expansion rate, phyllochron, and assimilate partitioning between roots and shoot varied in distinct lucerne growth stages 


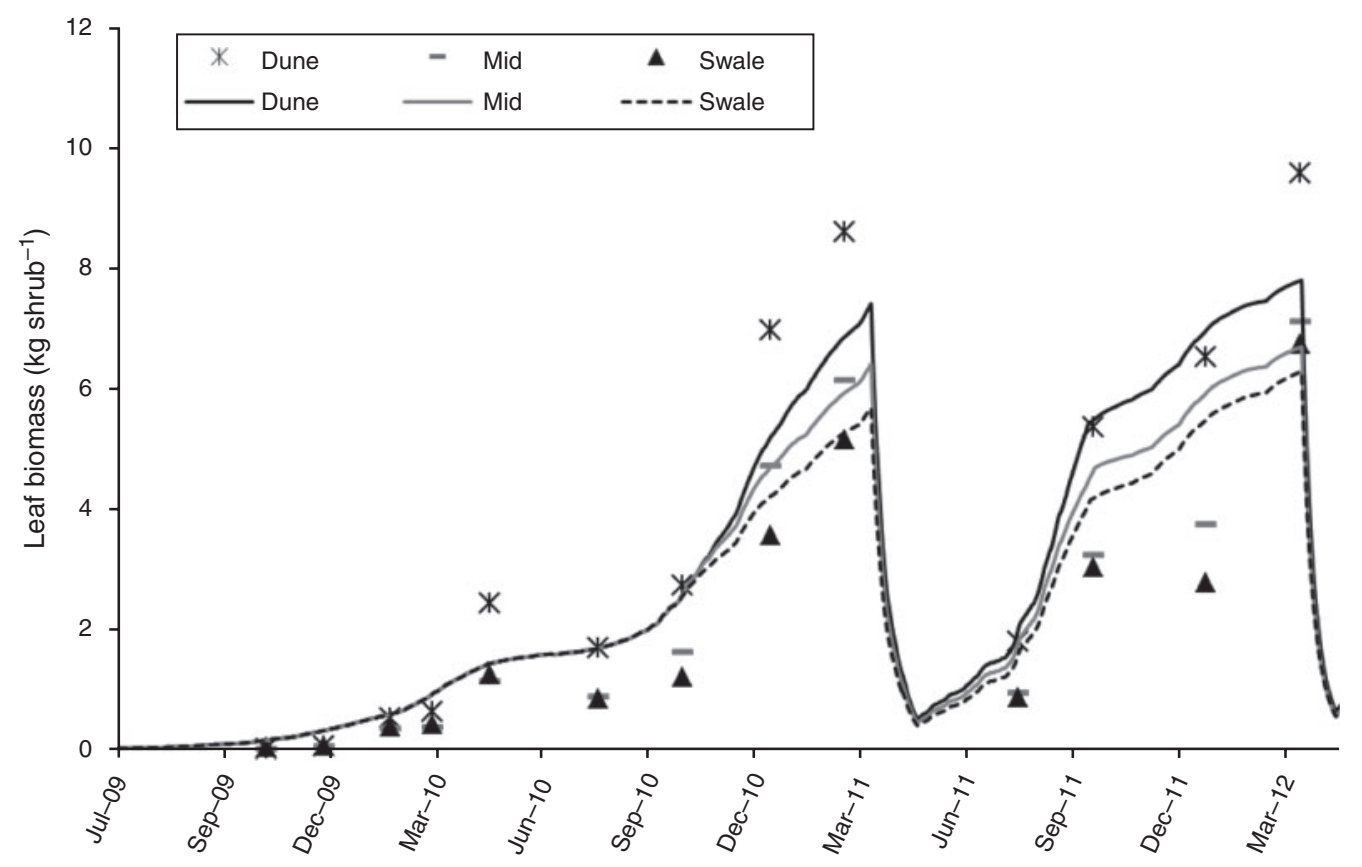

Fig. 9. Model predictions and observations of leaf biomass for Eyres saltbush at three landscape positions (dune, black line and stars; mid, grey line and rods; swale, dotted line and triangles) with a time-dependent radiation-use efficiency of 0.85 and $1.5 \mathrm{~g} \mathrm{MJ}^{-1}$ and parameters of Table 1.

(Teixeira et al. 2011). For saltbush itself, no direct observations of changes in RUE over time are available. However, laboratory studies have shown that saltbush root growth is most pronounced in the early growth stages, characterised by a greater root: shoot ratio than the later growth stages (Jones and Hodgkinson 1970). Because the current saltbush model does not predict root biomass production, a lower RUE for aboveground biomass production in the early growth stages reflects the greater partitioning of biomass to roots in these stages. The RUE values that were derived in this study are in line with RUE values of other plant modules in APSIM, varying from 0.9 to $1.2 \mathrm{~g} \mathrm{MJ}^{-1}$ (Robertson et al. 2002). However, the big difference in RUE between the two clonal cultivars is remarkable. According to Hammer et al. (2010), the reasons for such differences within the same species might be associated with differences in net photosynthetic rate or root-shoot partitioning. Also, the difference in growth pattern of the two saltbush types might be an explanation. Eyres saltbush exhibits a spreading growth pattern, which allows more light to penetrate the canopy than with the oblong and compact canopy of Waikerie saltbush, in which internal leaves are shaded. The model did indeed capture these differences in canopy architecture. However, besides the time-dependent RUE, other model parameter settings were not able to reproduce the difference in biomass production between the two types. Therefore, based on the current dataset, a decisive explanation is not possible.

Regrowth after defoliation by grazing is an important feature of saltbush plantations in farming systems. An adequate model representation of this process is therefore essential, and achieved in a satisfactory way by the present model. The key mechanism responsible for simulating leaf biomass recovery is biomass partitioning, governed by Eqns 1 and 2. With this mechanism, plants direct assimilates first to leaf biomass to restore allometry before assimilates are directed to woody biomass. Indeed, after defoliation, the plants can take advantage of the established woody architecture of stems and branches, as well as reserves present in the root and stem systems. Findings that defoliation reduced the rate of root extension in saltbush (Jones and Hodgkinson 1970) also confirm our observation of vigorous re-establishment of the leafy canopies, as the latter can only be explained by the fact that plants direct more assimilates to foliage production and less to, for example, root development. Other studies describing the good recovery of saltbush species after grazing (e.g. RuizMirazo and Robles 2011) confirm our observations of vigorous regrowth.

The growth, development and functioning of the root system was an area of uncertainty in the field experiment and, therefore, also in the model. Very few published studies are available on the root system parameters of saltbush, which consequently were derived mostly through model fitting. Sharma (1976) investigated saltbush plants growing in a soil from Deniliquin (New South Wales) with similar constraints to those of the mid and swale position in the present study, and they found little evidence of rooting activity below $75 \mathrm{~cm}$. This was the maximum rooting depth we independently derived for the swale soil (Table 1). Jones and Hodgkinson (1970) observed the majority of A. nummularia roots in the upper $50-100 \mathrm{~cm}$ of a soil, but they also encountered a few roots as deep as $3.5 \mathrm{~m}$ and up to $10 \mathrm{~m}$ distance from the stem. The rooting depths we found by model fitting (Table 1) are further supported by findings of a comprehensive literature review on root systems in water-limited ecosystems (Schenk and Jackson 2002). Based on their proposed regression function relating rooting depth with mean annual 

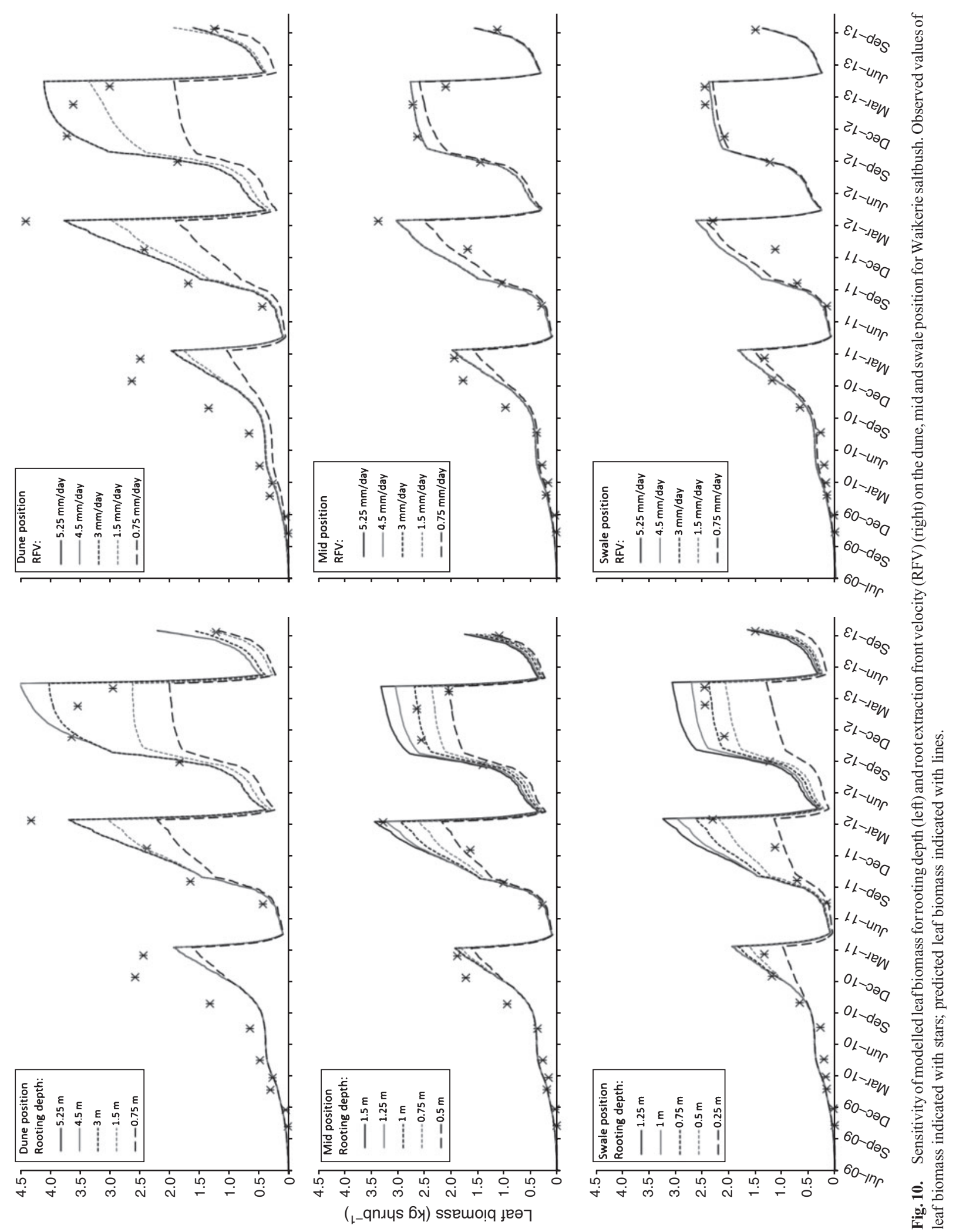
rainfall, Waikerie's average annual rainfall of $250 \mathrm{~mm}$ would correspond with a rooting depth of $2.1 \mathrm{~m}$. This lies in between the rooting depths derived for the dune and the swale position in the landscape experiment. Based on the sensitivity analysis, we chose to work with an average RFV of $3 \mathrm{~mm} \mathrm{day}^{-1}$, which is lower than the reported values for other species in APSIM (Robertson et al. 2002), and for other woody perennials such as Eucalyptus (Huth et al. 2008). The low RFV of saltbush that we found might be due to the low planting density and a symptom of the extraction front lagging behind the actual root front because of low water demand. Reported values of root extension rates for saltbush are much higher, at $8 \mathrm{~cm} \mathrm{day}^{-1}$ (Jones 1970; Hodgkinson and Becking 1978), but these were derived in controlled ideal conditions of temperature and water availability, and not very realistic for field conditions. The sensitivity analysis showed that a lower RFV on the mid and swale positions allowed better capture of slow growth in the early stages. Such a lower value would be in line with evidence showing that soil constraints slow down root front velocity (Rodriguez et al. 2006; Kirkegaard and Lilley 2007). Given the model simplifications due to restrictions in data availability, future data collection on the root system would help in model refinement. In particular, information on rooting depth, lateral root extension, root front velocity and root: shoot ratios, and how they are affected by environmental conditions such as soil moisture content, would be useful. Furthermore, with the model being very sensitive to the maximum rooting depth, its accurate assessment in the field is a prerequisite for accurate model predictions.

Biomass production is clearly driven by water availability. In the year of establishment, differences in biomass production between the landscape positions start to increase when the maximum rooting depth is reached on the mid and swale positions in May and February 2010, respectively (simulated dates). From then onwards, the available soil water is exhausted rapidly and water stress starts suppressing biomass production from November and March 2011 for the mid and swale positions. On the dune position, the maximum rooting depth of $3 \mathrm{~m}$ is reached only in March 2012 (simulated date), and the large water reserves in the soil enabled the strong early growth of the first 3 years. Once the deeper soil-water reserves are exhausted, however, biomass production is suppressed by water stress and it fully depends on rainfall (from October 2012 onwards). A levelling off or even a decline in leaf biomass in dry conditions such as in the summer of 2013 is therefore common when soil moisture reserves have been depleted, as observed by Wilmot and Norman (2006). Long-term simulation modelling using climate datasets of several years showed that as long as shrubs are accessing deep water reserves by expanding their root system, transpiration can exceed rainfall and biomass production is not driven by the amount of rain. This situation can last for up to 2-3 years for deep soils such as on the dune position or for $<1$ year for soils with subsoil constraints such as on the swale position.

Soil variability within the dune-swale landscape typical for the Mallee is a recognised landscape phenomenon, related to aeolian processes (Lievers and Luke 1980; Hopley and Robinson 2010). Dunes, located on the top of the catena, are usually deep, sandy soils with low water-holding capacity and poor fertility.
On the swale positions, soils are often characterised by subsoil constraints in the form of boron and/or accumulated salts and by heavier clay texture starting at shallow depth below the surface. These typical characteristics were present in the landscape experiment, where a deep, light loamy sand on the dune position made way to a soil with a heavy-textured subsoil from the mid-slope position downwards. In the model, the spatial variability in productive potential was captured by differences in water-retention characteristics and rooting depth for the three landscape positions (Table 3). The differences in maximum rooting depth were corroborated by the difficulties experienced during soil sampling to go beyond $1 \mathrm{~m}$ on the mid and swale position. Such difficulties were not encountered on the dune position.

Although the model was not developed based on data for saline environments, it can be used tentatively to explore the effects of reduced rooting depth due to high salt content and/or waterlogging. The long-term average leaf biomass production per shrub would be reduced to $70 \%$ and $13 \%$ of the biomass production on a 3-m-deep soil if the rooting depth was restricted to 0.5 and $0.2 \mathrm{~m}$, respectively. To mimic the effect of waterlogging in a 0.5 -m-deep soil, the rooting depth was reset to $0.1 \mathrm{~m}$ every year, resulting in leaf biomass production being only $55 \%$ of that on a 3 -m-deep soil. Based on long-term averages, the difference with unconstrained soils was less pronounced than in the first couple of years, when shrubs on deep soils can still access deeper soil reserves. However, these indications take into account only the predicted effect of reduced rooting depth; to capture physiological effects of salinity on growth rates, data from saline environments should be used to refine the model.

The productivity of the saltbush in the field experiment, even in the very dry summer of 2012-13, supports the proposition that including shrub plantations to complement the feed-base of dryland mixed crop-livestock farms can be profitable (see also Monjardino et al. 2010). This study has demonstrated that this new module for the APSIM framework can be valuable for the analysis of forage systems where saltbush and/or other woody perennials are important. The outputs from the model in conjunction with other feed-budgeting tools (Bell et al. 2008) can be used by graziers to plan grazing systems in response to seasonal variation in production by different feed sources and to select locations for forage shrub plantings based on soil type. With the modular capacity of APSIM, different perennial and annual plant options for the inter-row area can also be explored, complementing traditional field experimental approaches, which are expensive and time-consuming (e.g. Unkovich et al. 2003).

The model showed that leaf biomass from regrowth after grazing can potentially amount to $1.5-3 \mathrm{tha}^{-1}$ for Waikerie saltbush and 4-6 tha $\mathrm{t}^{-1}$ for Eyres saltbush at the start of autumn each year. After the first years in which the root systems develop, the simulated year-to-year potential biomass production was determined by rainfall amount. Actual growth will be further restricted by nutrient and soil chemical and physical limitations, as well as inter- and intra-species competition (Davidson et al. 1996; Bennett et al. 2009; Barrett-Lennard et al. 2013). For the simulation of actual systems, more information on the ecophysiology (e.g. shrub 
root systems in different soils, factors influencing senescence) and the nutritional quality of saltbush is required, as well as information on the factors influencing actual saltbush intake by livestock (Masters et al. 2005; Ben Salem et al. 2010). However, by allowing the simultaneous simulation of interacting saltbush and inter-row vegetation such as herbaceous pasture or crops, this model now enables the assessment of the forage value of complex, shrub-based systems. Also, the effects of climate variability on feed supply of farms containing saltbush plantations can be assessed, allowing supplementary feeding requirements to be quantified. Finally, because the saltbush model is linked to the APSIM framework, simulating saltbush growth on hostile soils is possible by adjusting the soil characteristics. These are important steps forward in the ability to dynamically assess the increasingly diverse feed-base of mixed farming systems.

\section{Conclusion}

The cost of supplementary feeding of livestock through periods of feed scarcity is a major limitation in many extensive animalproduction systems. Perennial forage shrubs such as saltbush species complement annual plant systems in climates with long, dry summers because of their summer-based growth pattern. A new model is now available for predicting biomass production and regrowth after grazing across soil types. Long-term sustainable biomass production can be assessed, which goes beyond the exploitative early growth observed in the first years of plantation establishment, and often in the full life of many shrub experiments. The model adds to the APSIM library of tools for planning and design of systems where the grazing of forage shrubs plays a role. Model outputs can inform strategic and tactical decisions on the inclusion and management of forage shrubs on crop-livestock farms.

\section{Acknowledgements}

This study is part of the CRC Future Farm Industries EverCrop project, funded by the Grains Research \& Development Corporation and the CSIRO Sustainable Agriculture Flagship. The contribution of Allen Buckley and the Mallee Sustainable Farming group to the field research at Waikerie is gratefully acknowledged.

\section{References}

Andrew MH, Noble I, Lange RT (1976) A non-destructive method for estimating the weight of forage on shrubs. Australian Rangelands Journal 1, 225-231. doi:10.1071/RJ9790225

Barrett-Lennard E, Galloway R (1996) Saltbush for water table reduction and land rehabilitation. Australian Journal of Soil and Water Conservation 9, 21-24.

Barrett-Lennard EG, Malcolm CV (1999) Increased concentrations of chloride beneath stands of saltbushes (Atriplex species) suggest substantial use of groundwater. Australian Journal of Experimental Agriculture 39, 949-955. doi:10.1071/EA99068

Barrett-Lennard EG, Malcolm CV, Bathgate A (2003) 'Saltland pastures in Australia - a practical guide.' 2nd edn. Sustainable Grazing on Saline Lands (a sub-program of Land, Water and Wool). (Land \& Water Australia: Canberra, ACT)

Barrett-Lennard EG, Bennett SJ, Altman M (2013) Survival and growth of perennial halophytes on saltland in a Mediterranean environment is affected by depth to watertable in summer as well as subsoil salinity. Crop \& Pasture Science 64, 123-136. doi:10.1071/CP12416

Barson MM, Abraham B, Malcolm CV (1994) Improving the productivity of saline discharge areas: an assessment of the potential use of saltbush in the Murray-Darling Basin. Australian Journal of Experimental Agriculture 34, 1143-1154. doi:10.1071/EA9941143

Bell LW, Robertson MJ, Revell DK, Lilley JM, Moore AD (2008) Approaches for assessing some attributes of feed-base systems in mixed farming enterprises. Australian Journal of Experimental Agriculture 48, 789-798. doi:10.1071/EA07421

Bell LW, Ryan MH, Bennett RG, Collins MT, Clarke HJ (2012) Growth, yield and seed composition of native Australian legumes with potential as grain crops. Journal of the Science of Food and Agriculture 92, 1354-1361. doi:10.1002/jsfa.4706

Ben Salem B, Norman HC, Nefzaoui A, Mayberry DE, Pearce KL, Revell DK (2010) Potential use of oldman saltbush (Atriplex nummularia Lindl.) in sheep and goat feeding. Small Ruminant Research 91, 13-28. doi:10.1016/j.smallrumres.2009.10.017

Bennett SJ, Barrett-Lennard EG, Colmer TD (2009) Salinity and waterlogging as constraints to saltland pasture production: a review. Agriculture, Ecosystems \& Environment 129, 349-360. doi:10.1016/j.agee.2008. 10.013

Collard SJ, Fisher AM (2010) Shrub-based plantings of woody perennial vegetation in temperate Australian agricultural landscapes: what benefits for native biodiversity? Ecological Management \& Restoration 11, 31-35. doi:10.1111/j.1442-8903.2010.00510.x

Davidson NJ, Galloway R, Lazarescu G (1996) Growth of Atriplex amnicola on salt-affected soils in Western Australia. Journal of Applied Ecology 33, 1257-1266. doi: $10.2307 / 2404768$

Dear BS, Ewing MA (2008) The search for new pasture plants to achieve more sustainable production systems in southern Australia. Australian Journal of Experimental Agriculture 48, 387-396. doi:10.1071/ EA07105

Dolling PJ, Robertson MJ, Asseng S, Ward PR, Latta RA (2005) Simulating lucerne growth and water use on diverse soil types in a Mediterraneantype environment. Australian Journal of Agricultural Research 56, 503-515. doi:10.1071/AR04216

Duursma RA, Makela A (2007) Summary models for light interception and light-use efficiency of non-homogeneous canopies. Tree Physiology 27, 859-870. doi:10.1093/treephys/27.6.859

Ellis EA, Bentrup G, Schoeneberger MM (2004) Computer-based tools for decision support in agroforestry: Current state and future needs. Agroforestry Systems 61, 401-421. doi:10.1023/B:AGFO.0000029015. 64463.65

Estell RE, Havstad KM, Cibils AF, Fredrickson EL, Anderson DM, Schrader TS, James DK (2012) Increasing shrub use by livestock in a world with less grass. Rangeland Ecology and Management 65, 553-562. doi:10.2111/REM-D-11-00124.1

Friday JB, Fownes JH (2001) A simulation model for hedgerow light interception and growth. Agricultural and Forest Meteorology 108, 29-43. doi:10.1016/S0168-1923(01)00220-9

Gates CT, Muirhead W (1967) Studies of the tolerance of Atriplex species. I. Environmental characteristics and plant response of $A$. vesicaria, A. nummularia and A. semibaccata. Australian Journal of Experimental Agriculture and Animal Husbandry 7, 39-49. doi:10.10 71/EA9670039

George RJ, Nulsen RA, Ferdowsian R, Raper GP (1999) Interactions between trees and groundwaters in recharge and discharge areas- $\mathrm{A}$ survey of Western Australian sites. Agricultural Water Management 39, 91-113. doi:10.1016/S0378-3774(98)00073-0

Hammer GL, van Oosterom E, McLean G, Chapman SC, Broad I, Harland P, Muchow RC (2010) Adapting APSIM to model the physiology and genetics of complex adaptive traits in field crops. Journal of Experimental Botany 61, 2185-2202. doi:10.1093/jxb/erq095 
Hodgkinson KC, Becking HGB (1978) Effect of defoliation on root growth of some arid zone perennial plants. Australian Journal of Agricultural Research 29, 31-42. doi:10.1071/AR9780031

Holzworth DP, Huth NI, deVoil PG, Zurcher EJ, Herrmann NI, McLean G, Chenu K, van Oosterom E, Snow VO, Murphy C, Moore AD, Brown HE, Whish JPM, Verrall S, Fainges J, Bell LW, Peake AS, Poulton PL, Hochman Z, Thorburn PJ, Gaydon DS, Dalgliesh NP, Rodriguez D, Cox H, Chapman S, Doherty A, Teixeira E, Sharp J, Cichota R, Vogeler I, Li FY, Wang E, Hammer GL, Robertson MJ, Dimes J, Whitbread AM, Hunt J, van Rees H, MaClelland T, Carberry PS, Hargreaves JNG, MacLeod N, McDonald C, Harsdorf J, Wedgwood S, Keating BA (2014) APSIM - evolution towards a new generation of agricultural systems simulation. Environmental Modelling \& Software, in press.

Hopley J, Robinson N (2010) Disaggregation of landform components within land systems of the Victorian Mallee using a digital elevation model. In 'Soil solutions for a changing world. Proceedings 19th World Congress of Soil Science'. 1-6 August 2010, Brisbane, Qld. Working Group 1.3 Digital soil assessment 20-23. (International Union of Soil Science) Available at: www.iuss.org/19th\%20WCSS/Symposium/pdf/ 1347.pdf

Huth NI, Carberry PS, Poulton PL, Brennan LE, Keating BA (2002) A framework for simulating agroforestry options for the low rainfall areas of Australia using APSIM. European Journal of Agronomy 18, 171-185. doi:10.1016/S1161-0301(02)00103-X

Huth NI, Carberry PS, Cocks B, Graham S, McGinness HM, O'Connell DA (2008) Managing drought risk in eucalypt seedling establishment: An analysis using experiment and model. Forest Ecology and Management 255, 3307-3317. doi:10.1016/j.foreco.2008.02.024

Huth NI, Robertson MJ, Poulton PL (2010) Regional differences in tree-crop competition due to soil, climate and management. Crop \& Pasture Science 61, 763-770. doi:10.1071/CP09254

Huth NI, Banabas M, Nelson PN, Webb M (2014) Development of an oil palm cropping systems model: Lessons learned and future directions. Environmental Modelling \& Software, in press.

Isbell RF (2002) 'The Australian Soil Classification.' (CSIRO Australia: Melbourne)

Jones R (1970) 'The biology of Atriplex'. (CSIRO Division of Plant Industry: Canberra, ACT)

Jones R, Hodgkinson KC (1970) Root growth of rangeland chenopods: morphology and production of Atriplex nummularia and Atriplex vesicaria. In 'The biology of Atriplex'. (Ed. R Jones) pp. 77-85. (CSIRO Division of Plant Industry: Canberra, ACT)

Keating BA, Carberry PS, Hammer GL, Probert ME, Robertson MJ, Holzworth D, Huth NI, Hargreaves JNG, Meinke H, Hochman Z, McLean G, Verburg K, Snow V, Dimes JP, Silburn M, Wang E, Brown S, Bristow KL, Asseng S, Chapman S, McCown RL, Freebairn DM, Smith CJ (2003) An overview of APSIM, a model designed for farming systems simulation. European Journal of Agronomy 18, 267-288. doi:10.1016/S1161-0301(02)00108-9

Kirkegaard JA, Lilley JM (2007) Root penetration rate-a benchmark to identify soil and plant limitations to rooting depth in wheat. Australian Journal of Experimental Agriculture 47, 590-602. doi:10.1071/EA06071

Knight A, Blott K, Portelli M, Hignett C (2002) Use of tree and shrub belts to control leakage in three dryland cropping environments. Australian Journal of Agricultural Research 53, 571-586. doi:10.1071/ AR01089

Kok B, George PR (1986) Saltland revegetation with salt tolerant shrubs. In 'Rangelands: a resource under siege. Proceedings 2nd International Rangeland Congress'. 13-18 May 1984, Adelaide, Australia. pp. 176-177. (University of Cambridge Press: Cambridge, UK)

Le Houérou HN (1992) The role of saltbushes (Atriplex spp.) in arid land rehabilitation in the Mediterranean Basin: a review. Agroforestry Systems 18, 107-148.
Le Houérou HN (2000) Utilization of fodder trees and shrubs in the arid and semiarid zones of West Asia and North Africa. Arid Soil Research and Rehabilitation 14, 101-135. doi:10.1080/089030600263058

Lefroy EC, Stirzaker RJ, Pate JS (2001) The influence of tagasaste (Chamaecytisus proliferus Link.) trees on the water balance of an alley cropping system on deep sand in south-western Australia. Australian Journal of Agricultural Research 52, 235-246. doi:10.1071/AR00035

Lievers RL, Luke DO (1980) Problems associated with arable agriculture in mallee landscapes in Victoria. In 'Aeolian landscapes in the semi-arid zone of south-eastern Australia. Proceedings of Conference'. 17-18 October 1979, Mildura, Vic., pp. 219-227. (Australian Society of Soil Science Riverina Branch)

Llewellyn RS, Whitbread A, Lawes R, Raisbeck-Brown N, Hill P (2010) Fork in the road: forage shrub plantings by crop-livestock farmers in a low rainfall region of southern Australia. In 'Food security from sustainable agriculture. Proceedings 15th Australian Agronomy Conference'. November 14-18, Lincoln, New Zealand. (Australian Society of Agronomy/The Regional Institute Ltd: Gosford, NSW) Available at: www.regional.org.au/au/asa/2010/pastures-forage/dryland-perennials/71 79_llewellynr.htm

Llewellyn R, Robertson MJ, Hayes R, Ferris D, Revell C, Descheemaeker K (2013) A strategic approach to developing the role of perennials for croplivestock farmers. In 'Revitalising grasslands to sustain our communities. Proceedings 22nd International Grassland Congress'. 15-19 September 2013, Sydney. (Eds DL Michalk, GD Millar, WB Badgery, KM Broadfoot) pp. 940-946. (International Grasslands Congress/NSW Department of Primary Industries: Orange, NSW)

Masters DG, Rintoul AJ, Dynes RA, Pearce KL, Norman HC (2005) Feed intake and production in sheep fed diets high in sodium and potassium. Australian Journal of Agricultural Research 56, 427-434. doi:10.1071/ AR04280

Meinke H, Hammer GL, Want P (1993) Potential soil-water extraction by sunflower on a range of soils. Field Crops Research 32, 59-81. doi:10.1016/0378-4290(93)90021-E

Milthorpe PL, Honeysett BM, Patton DA, Wynne MJ (2001) Integration of alternative forage sources in drought management. Final Report of Program 6, Drought Regional Initiatives Program. New South Wales Agriculture, Orange, NSW.

Monjardino M, Revell D, Pannell DJ (2010) The potential contribution of forage shrubs to economic returns and environmental management in Australian dryland agricultural systems. Agricultural Systems 103, 187-197. doi:10.1016/j.agsy.2009.12.007

Monjardino M, McBeath TM, Brenan LE, Llewellyn RS (2013) Are farmers in low-rainfall cropping regions under-fertilising with nitrogen? A risk analysis. Agricultural Systems 116, 37-51. doi:10.1016/j. agsy.2012.12.007

Monjardino M, Bathgate A, Llewellyn R (2014) Opportunities for plant improvement to increase the value of forage shrubs on low-rainfall mixed farms. Crop \& Pasture Science 65, 1057-1067.

Monteith JL, Unsworth MJ (1990) 'Principles of environmental physics.' 2nd edn (Edward Arnold: New York)

Moore AD, Bell LW, Revell DK (2009) Feed gaps in mixed-farming systems: insights from the Grain \& Graze program. Animal Production Science 49, 736-748. doi:10.1071/AN09010

Muetzelfeldt RI (1995) A framework for a modular modelling approach for agroforestry. Agroforestry Systems 30, 223-234. doi:10.1007/BF00 708922

Nichols PGH, Loi A, Nutt BJ, Evans PM, Craig AD, Pengelly BC, Dear BS, Lloyd DL, Revell CK, Nair RM, Ewing MA, Howieson JG, Auricht GA, Howie JH, Sandral GH, Carr SJ, de Koning CT, Hackney BF, Crocker GJ, Snowball R, Hughes SJ, Hall EJ, Foster KJ, Skinner PW, Barbetti MJ, You MP (2007) New annual and short-lived perennial pasture legumes for Australian agriculture-15 years of revolution. Field Crops Research 104, 10-23. doi:10.1016/j.fcr.2007.03.016 
Norman HC, Masters DG, Wilmot MG, Rintoul AJ (2008) Effect of supplementation with grain, hay or straw on the performance of weaner Merino sheep grazing old man (Atriplex nummularia) or river (Atriplex amnicola) saltbush. Grass and Forage Science 63, 179-192. doi:10.1111/j.1365-2494.2007.00623.x

Norman HC, Wilmot MG, Thomas DT, Barrett-Lennard EG, Masters DG (2010) Sheep production, plant growth and nutritive value of a saltbush-based pasture system subject to rotational grazing or set stocking. Small Ruminant Research 91, 103-109. doi:10.1016/j. smallrumres.2009.11.022

Norman HC, Masters DG, Barrett-Lennard EG (2013) Halophytes as forages in saline landscapes: interactions between plant genotype and environment change their feeding value to ruminants. Environmental and Experimental Botany 92, 96-109. doi:10.1016/j.envexpbot.2012. 07.003

O'Connell M, Young J, Kingwell R (2006) The economic value of saltland pastures in a mixed farming system in Western Australia. Agricultural Systems 89, 371-389. doi:10.1016/j.agsy.2005.10.003

Papanastasis VP, Yiakoulaki MD, Decandia M, Dini-Papanastasi O (2008) Integrating woody species into livestock feeding in the Mediterranean areas of Europe. Animal Feed Science and Technology 140, 1-17. doi:10.1016/j.anifeedsci.2007.03.012

Probert ME, Dimes JP, Keating BA, Dalal RC, Strong WM (1998) APSIM's water and nitrogen modules and simulation of the dynamics of water and nitrogen in fallow systems. Agricultural Systems 56, 1-28. doi:10.1016/ S0308-521X(97)00028-0

Revell DK, Norman HC, Vercoe PE, Phillips N, Toovey A, Bickell S, Hulm E, Hughes S, Emms J (2013) Australian perennial shrub species add value to the feed base of grazing livestock in low- to medium-rainfall zones. Animal Production Science 53, 1221-1230. doi:10.1071/AN13238

Robertson MJ, Carberry PS, Huth NI, Turpin JE, Probert ME, Poulton PL, Bell M, Wright GC, Yeates SJ, Brinsmead RB (2002) Simulation of growth and development of diverse legume species in APSIM. Australian Journal of Agricultural Research 53, 429-446. doi:10. 1071/AR01106

Rodriguez D, Nuttall J, Sadras VO, Rees HV, Armstrong R (2006) Impact of subsoil constraints on wheat yield and gross margin on fine-textured soils of the southern Victorian Mallee. Australian Journal of Agricultural Research 57, 355-365. doi:10.1071/AR04133

Ruiz-Mirazo J, Robles AB (2011) Short- and medium-term response of Atriplex halimus L. to repeated seasonal grazing in south-eastern Spain. Journal of Arid Environments 75, 586-595. doi:10.1016/j.jari denv.2011.01.012

Schenk HJ, Jackson RB (2002) Rooting depths, lateral root spreads and below-ground/above-ground allometries of plants in water-limited ecosystems. Journal of Ecology 90, 480-494. doi:10.1046/j.13652745.2002.00682.x

Seddon J, Doyle S, Bourne M, MacCallum R, Briggs S (2009) Biodiversity benefits of alley farming with old man saltbush in central western New South Wales. Animal Production Science 49, 860-868. doi:10.1071/ EA08280
Sharma ML (1976) Soil water regimes and water extraction patterns under two semi-arid shrub (Atriplex spp.) communities. Australian Journal of Ecology 1, 249-258. doi:10.1111/j.1442-9993.1976.tb01114.x

Sochacki SJ, Harper RJ, Smettem KRJ (2012) Biol.-mitigation of carbon following afforestation of abandoned salinized farmland. Global Change Biology - Bioenergy 4, 193-201. doi:10.1111/j.1757-17 07.2011.01139.x

Teixeira EI, Brown HE, Meenken ED, Moot DJ (2011) Growth and phenological development patterns differ between seedling and regrowth lucerne crops (Medicago sativa L.). European Journal of Agronomy 35, 47-55. doi:10.1016/j.eja.2011.03.006

Thiébeau P, Beaudoin N, Justes E, Allirand JM, Lemaire G (2011) Radiation use efficiency and shoot : root dry matter partitioning in seedling growths and regrowth crops of lucerne (Medicago sativa L.) after spring and autumn sowings. European Journal of Agronomy 35, 255-268. doi:10.1016/j.eja.2011.07.002

Thomas DT, White CL, Hardy J, Collins JP, Ryder A, Norman HC (2009) An on-farm evaluation of the capability of saline land for livestock production in southern Australia. Animal Production Science 49, 79-83. doi:10.1071/EA08122

Unkovich M, Blott K, Knight A, Mock I, Rab A, Portelli M (2003) Water use, competition, and crop production in low rainfall, alley farming systems of south-eastern Australia. Australian Journal of Agricultural Research 54, 751-762. doi:10.1071/AR03049

Van Noordwijk M, Lusiana B (1998) WaNuLCAS, a model of water, nutrient and light capture in agroforestry systems. Agroforestry Systems 43, 217-242. doi:10.1023/A:1026417120254

Van Noordwijk M, Lawson G, Groot JJR, Hairiah K (1996) Root distribution in relation to nutrients and competition. In 'Tree-crop interactions - a physiological approach'. (Eds CK Ong, PA Huxley) pp. 319-364. (CAB International: Wallingford, UK)

Warren BE, Bunny CJ, Bryant ER (1990) A preliminary examination of the nutritive value of four saltbush (Atriplex) species. Proceedings of the Australian Society of Animal Production 18, 424-427.

Whitbread A, Llewellyn R, Gobbett D, Davoren B (2008) EM38 and cropsoil simulation modelling can identify differences in potential crop performance on typical soil zones in the Mallee. In 'Global issues, paddock action. Proceedings of 14th Agronomy Conference'. 21-25 September 2008, Adelaide, S. Aust. (Ed. M Unkovich) (Australian Society of Agronomy/The Regional Institute Ltd: Gosford, NSW) Available at: www.regional.org.au/au/asa/2008/poster/agronomy-land scape/5823_whitbread.htm

Wilmot MG, Norman HC (2006) Saltbush biomass in a saline grazing system - use it or lose it. In 'Proceedings 26th Biennial Conference Australian Society of Animal Production'. 9-14 July 2006, University of Western Australia, Perth. Vol. 26. Short communication No. 9. (CSIRO Publishing: Melbourne)

Wilson AD (1994) Halophytic shrubs in semi-arid regions of Australia. In 'Halophytes as a resource for livestock and for rehabilitation of degraded lands'. Vol. 32. (Eds V Squires, A Ayoub) pp. 101-113. (Springer: Dordrecht, The Netherlands) 